\title{
A risk society? Environmental hazards, risk and resilience in the later Middle Ages in Europe
}

\author{
Christopher M. Gerrard • David N. Petley
}

Received: 11 February 2013/ Accepted: 29 May 2013/Published online: 15 June 2013

(C) The Author(s) 2013. This article is published with open access at Springerlink.com

\begin{abstract}
Modern society is said to have restructured in reaction to contemporary hazards with the aim of improving its management of risk. This implies that pre-industrial societies were somehow fundamentally different. In this paper, we challenge that hypothesis by examining the ways in which risks associated with environmental hazards were managed and mitigated during the Middle Ages (defined here as the period from 1000 to $1550 \mathrm{AD}$ ). Beginning with a review of the many case studies of rapid onset disasters across Europe, we draw upon both historical and archaeological evidence and architectural assessments of structural damage for what is a pre-instrumental period. Building upon this, the second part of the paper explores individual outlooks on risk, emphasising the diversity of popular belief and the central importance of Christianity in framing attitudes. Despite their religious perspectives, we find that medieval communities were not helpless in the face of serious environmental hazards. We argue instead that the response of society to these threats was frequently complex, considered and, at times, surprisingly modern.
\end{abstract}

Keywords Hazard · Risk · Medieval · Europe $\cdot$ Archaeology

\section{Introduction}

The notion of a 'risk society' is underpinned by the proposal that contemporary organisational structures are generated by responses to 'hazards and insecurities induced and introduced by modernization itself' (Beck 1992, p. 21). Risks specifically associated with modernity, such as those rooted in chemical, nuclear and information technologies, are

C. M. Gerrard

Department of Archaeology, Durham University, Durham DH1 3LE, UK

e-mail: c.m.gerrard@durham.ac.uk

D. N. Petley $(\bowtie)$

Department of Geography, Durham University, Durham DH1 3LE, UK

e-mail: d.n.petley@durham.ac.uk 
considered to be especially powerful and, while the 'risk society' concept recognises that communities have also been subject to hazards in the past, these are judged to have been imposed by external forces. In this paper, we challenge that analysis through a review of the nature of, and responses to, natural hazards across Christian Europe during the Middle Ages (loosely defined here as 1000-1550 AD).

The roll-call of disasters during the later medieval period was a lengthy one. Not only did communities respond continually to environmental hazards, their effects were also felt sometimes across the whole of Europe in a way that has not been observed in modern times. In 1258 the largest volcanic eruption of the last 7,000 years affected the entire continent, while in 1315-1321 the most serious famine in recorded European history was driven by a prolonged period of low temperatures and heavy summer rainfalls associated with abnormally warm North Atlantic sea temperatures (Dawson et al. 2007). Other events such as the most powerful earthquake in central Europe in 1356, river floods, tsunamis in the Mediterranean and sea surges along north-western coastlines all affected specific regions so that responses by different communities can be usefully compared over roughly half a millennia. Here, our focus is primarily upon rapid onset disasters such as geophysical and hydrometeorological hazards (including some droughts), rather than chronic pollution from medieval tanneries or the cooling climate after 1250 (Mann et al. 2009; Pribyl et al. 2011). Losses associated with disease outbreaks are also excluded, as are astronomical phenomena such as comets and meteors whose impacts remain controversial in this period (Baillie 2006).

We begin with a brief review of the many case studies of rapid onset disasters, drawing upon both historical and archaeological evidence and architectural assessments of structural damage for what is a pre-instrumental period (Guidoboni and Ebel 2009). The second part of the paper then explores the individual perspective on risk and emphasises both the diversity of popular belief and the importance of Christianity in framing attitudes. Finally, we contest the assumption that medieval communities were somehow 'helpless' in the face of serious environmental hazards and show that their responses could be complex, considered and sometimes surprisingly modern.

\section{Environmental hazards}

\subsection{Earthquakes}

Italy, Greece, the Balkans, Switzerland and southern Spain all experienced high-magnitude seismic events during the Middle Ages (e.g. Boschi et al. 2000 for Italy; Papadopoulos and Fokaefs 2005 for Greece), but even relatively tectonically benign parts of Europe could suffer. Apart from its Norman West Front, Lincoln Cathedral was damaged beyond repair in an earthquake in 1185 (Pevsner and Metcalf 1985, 1, p. 201; Musson 2012). Much of the evidence for medieval earthquakes comes from historical documents, and evolving catalogues have to contend with the multiple reporting of events, often in different languages from various primary sources, as well as pronounced regional and chronological bias, and embellishment (e.g. Dominey-Howes 2002; Piccardi and Masse 2007; Schwarz-Zanetti et al. 2008). Whereas some accounts are only cursory, such as the Arabic inscription which describes the reconstruction of the minaret at the (now) Church of El Salvador, Seville (Spain), after an earthquake in 1079 (Ciccarello 1996), other events benefit either from multiple near-contemporary testimonies, the 1348 earthquake at Friuli in northern Italy 
being a well-studied example (Rohr 2003), or detailed lists of repairs, as is the case for the 1448 earthquake at Llinars in Catalonia (Salicrúi LLuch 1995).

Evidence for earthquake events, and for their impacts, can be revealed through an analysis of structural damage. Thus, the Roman aqueduct displaced by $0.9 \mathrm{~m}$ in the southcentral Apennines (Italy) during the 1349 earthquake acts both as a measure of geological faulting and a terminus post quem for the event itself (Galli and Naso 2009). However, the main contribution of medieval archaeoseismology (sensu Galadini et al. 2006) is in assessing impacts on standing buildings. Well-documented exemplars of seismic damage include the Abbazia di Santa Scolastica in the central Apennines (Italy; Molin et al. 2002) and the Duomo church in Syracuse (Sicily) with its misaligned columns $(>70 \mathrm{~cm})$, reinforced walls and dislodged column drums - the result of an earthquake in 1542 (Boschi et al. 1995). Analytical archaeological techniques have successfully identified the characteristic signs of collapse at the Hacienda de Miraflores (Seville, Spain), an early sixteenth-century building probably affected by an earthquake in April 1504 (Vargas Jiménez 2002), but this kind of evidence is notoriously difficult to authenticate when excavation is small in scale. Elsewhere, discrete impacts on the morphology of urban areas have sometimes been noted (e.g. for Baza in Spain in 1531; Espinar Moreno and Quesada Gómez 1991), but it is the contribution of excavation data gathered for the 1356 earthquake at Basel that best demonstrates the value of extensive and reliable archaeological records (Fig. 1). Here, sequences of burning and debris have been traced with levelling layers and rebuilding above, while valuable metal objects such as weapons and a bronze cauldron were among those hurriedly abandoned and subsequently buried (Fäh et al. 2009). Multiple reroofings across Basel following the 1356 episode have been verified with dendrochronology, but elsewhere clusters of similarly dated repairs and rebuildings have been used to create regional isoseismic maps. In this way, unusual 'swarms' of interventions have been identified in Romanesque churches in northern Italy damaged by the 1117 earthquake (Galadini and Galli 2001), while commemorative and dedicatory inscriptions on new buildings have been used to track seismic episodes on Crete in 1303 and 1513 (e.g. Kalopissi-Verti 1992). However, despite accumulating evidence of the primary impacts of seismic events in Europe, there remains no comprehensive synthesis of the data and no analyses of the likely range of events that do not yet appear in historical data sets.

Secondary seismic hazards have been little explored in the archaeological record, even though there is strong landscape evidence for earthquake-induced landslides, such as that which dammed the River Idrijca and demolished local cinnabar mines during the 1511 earthquake in West Slovenia (Fitzko et al. 2005; for examples in Italy and Portugal, see Boschi et al. 2000, and for the Azores, see Silveira et al. 2003). At least 16 tsunamis are also documented across the Mediterranean during the Middle Ages (Luque et al. 2001; Papadopoulos and Fokaefs 2005), three striking the Spanish coastline in the first half of the sixteenth century alone, though impacts on settlement patterns have not so far been observed archaeologically. Damage certainly occurred; the August 1303 tsunami, probably the largest of all the later medieval events, was generated by a powerful earthquake that affected the entire western Hellenic arc (Guidoboni and Comastri 1997; Scheffers et al. 2008). The sea waves that swept into Heraklion on Crete (then the Venetian colony of Candia) caused widespread destruction (Papadopoulos et al. 2007). The low profile of medieval and later archaeology in some countries is not the only explanation as to why these secondary hazards have not been more closely examined, and in the case of tsunamis, further constraints are imposed by changes to late Holocene coastlines (lagoons, storm barriers, etc.); the challenges of interpreting geomorphological and sedimentological records (Dominey-Howes 2002); and the limited archaeological evidence left behind by 


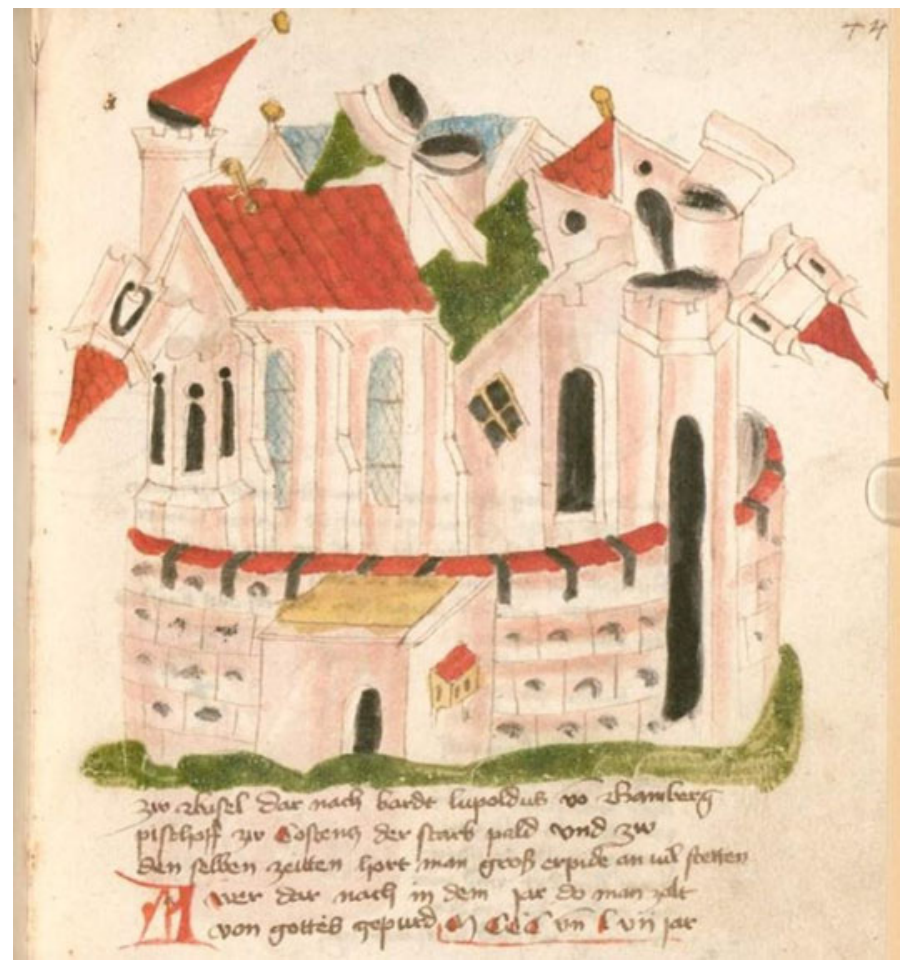

Fig. 1 Imaginative reconstruction of the Basel earthquake in the Konstanzer Weltchronik, a fourteenthcentury 'world chronicle' produced at Konstanzer in Germany (copyright Bayerische Staatsbibliothek München Cgm 426, fol. 44r)

even the most destructive tsunami when historic infrastructure is reconstructed soon afterwards, sometimes recycling the same materials.

\subsection{Volcanoes}

Large volcanic eruptions could cause extensive local damage; in 1408 and again in 1537, medieval Sicilian villages were engulfed by lava from Etna, for example (Chester et al. 2005). Far more serious, however, were the continental and even global scale changes in weather patterns induced by the most violent eruptions. Although the discernible wider effects of medieval eruptions of Etna, Vesuvius (Tinti and Maramai 1996; Nazzaro 1998) and possibly others in the Aegean volcanic arc (Stiros 2000) appear to be negligible, a number of other very large 'climate-forcing' eruptions are recorded. Those of 1028-1032 (possibly an eruption of Baitoushan in China/North Korea) and c.1453 (probably from Kuwae in Vanuatu) both lowered temperatures in the northern hemisphere (Oppenheimer 2003), but the most significant volcanic event of the historic period occurred in early 1258 , at an as yet undetermined location in the tropics. The volcanic aerosol veil it generated led in 1258 and 1259 to two of the coldest and wettest summers in the northern hemisphere in the last 1,000 years (Briffa et al. 1998), as well as to exceptionally cold European winters. Damage to crops and disease were rife, wheat prices in 1257-1258 rose 87 per cent higher than the mean of the previous 10 years, and severe famine was recorded across England, 


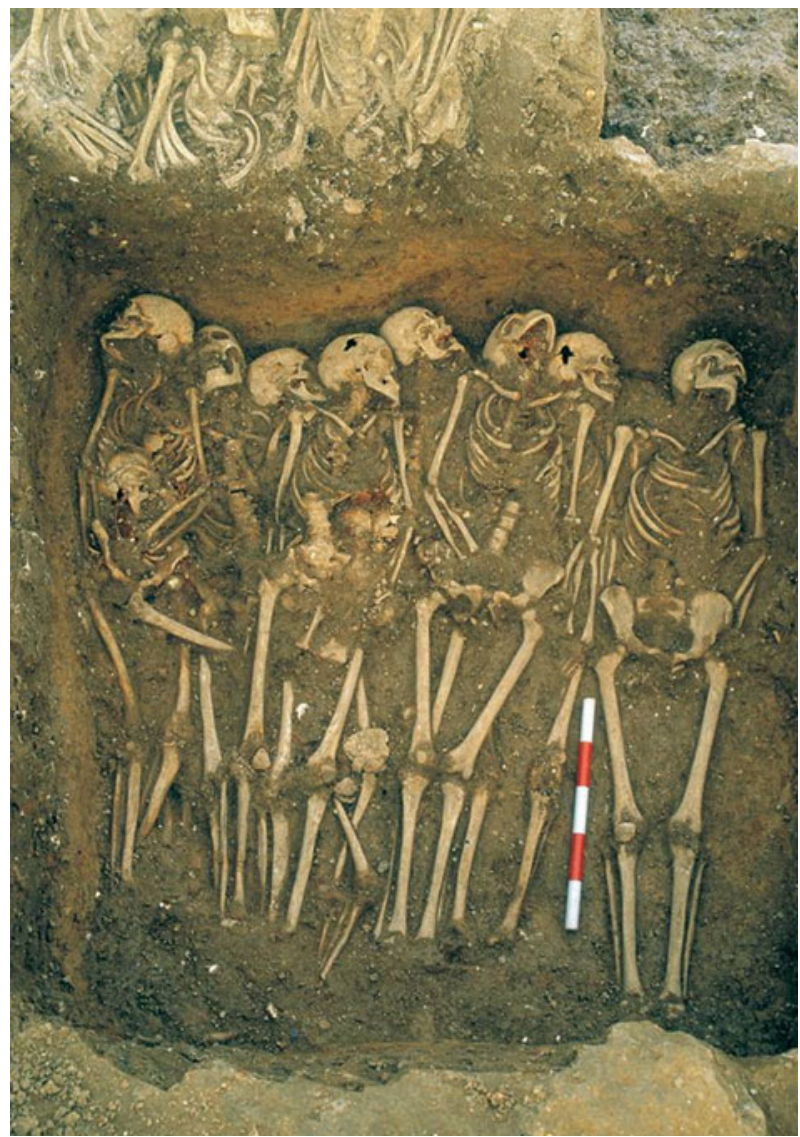

Fig. 2 Archaeological excavations at Spitalfields, London, revealed mass graves which have been linked to a volatile climate after a volcanic eruption in 1258 (copyright MOLA)

France, Germany and Italy, with widespread mortality from the starvation that followed (Stothers 1999, 2000; Keene 2011). Some of the burial pits excavated at the Spitalfields cemetery in London, associated with the medieval priory and hospital of St. Mary without Bishopsgate, are argued to contain the victims of the aftermath of this event (Fig. 2); a claim made possible only by the greater chronological precision offered by recent advances in Bayesian radiocarbon dating (Connell et al. 2012).

\subsection{Severe weather}

Damaging weather conditions were undoubtedly common in the Middle Ages, and there are many regional compilations (for difficulties, see Bell and Ogilvie 1978; Rohr 2007). Storms and lightning were often noted in written accounts, especially when their consequences proved costly. In the aftermath of floods, maximum water heights were sometimes notched on public buildings as testimony to the resilience of the inhabitants, a tradition which also served to extend public memory of especially damaging events (Fig. 3). Notable accounts of severe weather events include severe gales in Bohemia (e.g. Brázdil 
et al. 2005); storm surges in eastern England (Bailey 1991); floods on major rivers such as the Tiber/Po (Camuffo and Enzi 1996), Elbe/Vltava (Brázdil 1998) and Tagus (Benito and Machado 1998); and the deluge that overtopped the city walls of Cologne in 1372 (Herget and Meurs 2010).

Sometimes a direct link to a specific weather event can be established from architectural or archaeological evidence; a good example of this is the clear structural confirmation for the rebuilding of the upper clerestory of the presbytery of Norwich cathedral after it was struck by the falling spire in 1362 during a 'hurricane' (Pevsner and Metcalf 1985) (Fig. 4). Being tall, churches, cathedrals and monasteries were always vulnerable to lightning and gales (Morris 1989, p. 329). Another example is the replacement of bridges swept away by river floods, for which underwater investigation may reveal several phases of construction from medieval to modern (e.g. for the River Nore at Kilkenny, Ireland; Brady 2004). Landscape evidence can deliver compelling corroboration for disasters too, as it has for the largest recorded flood in central Europe in July 1342, which led to deep erosive gullying in northern Bavaria (Dotterweich et al. 2003), while to the south of Dordrecht (the

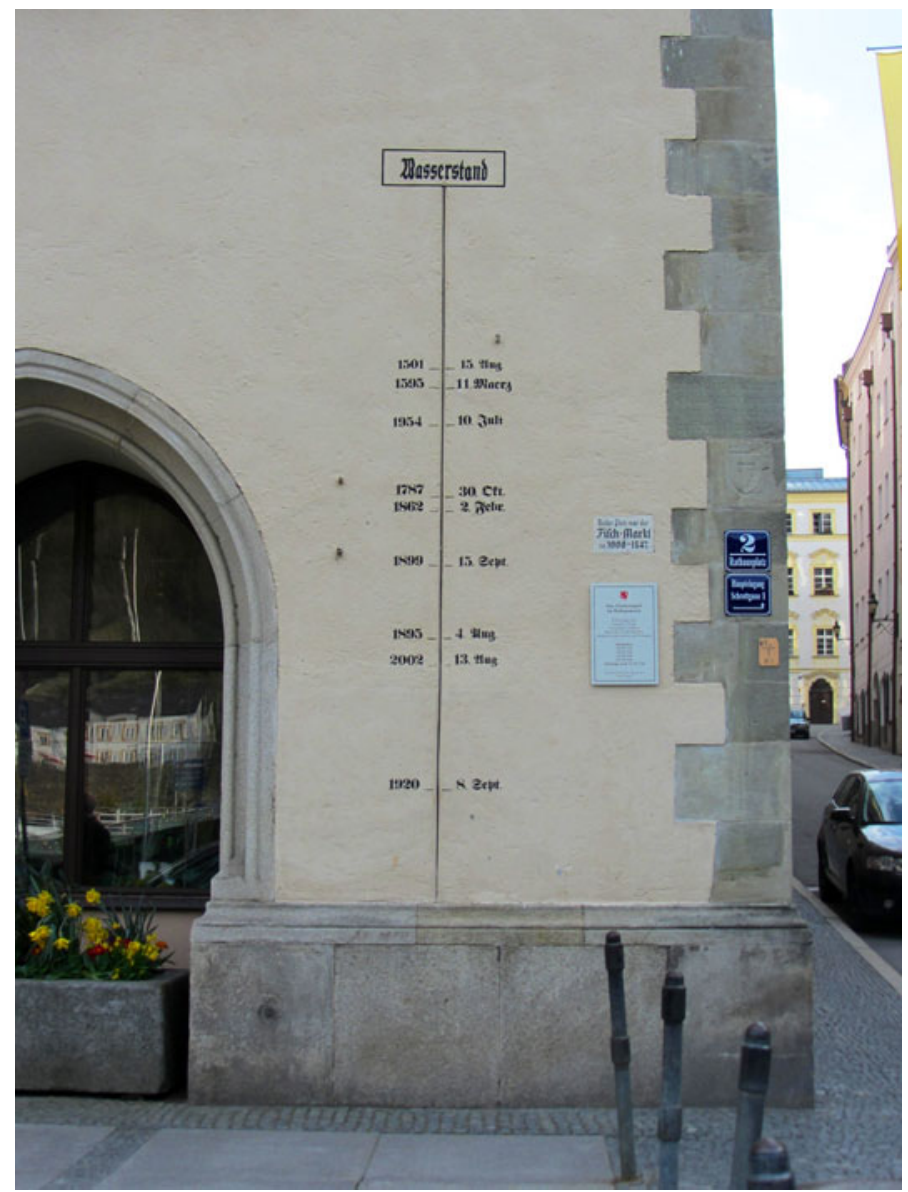

Fig. 3 Maximum water heights recorded at Passau in Lower Bavaria (Germany). The town lies at the confluence of the Danube, Inn and Ilz rivers and has regularly been flooded (courtesy of Sally Forwood) 
Netherlands), geomorphological and palaeohydrological research has been combined with archaeological evidence to investigate the flooding of $300 \mathrm{~km}^{2}$ of embanked land between 1421 and 1424 (Kleinhans et al. 2010). In urban contexts, the evidence is inevitably more vulnerable to removal, though alluvial sediments in the centre of Florence (Italy) have been convincingly linked to a catastrophic flood on the River Arno in November 1177 (Fedi et al. 2007), and in Islamic Valencia (Spain), several excavations have identified gravel and sand layers $60-80 \mathrm{~cm}$ thick burying houses, wells and cemeteries, the consequence of repeated flooding of the River Turia in the eleventh century. In one instance, the riverside quay was found to be buried beneath $2.5 \mathrm{~m}$ of fluvial sediments that were subsequently reexcavated for the foundations of the fourteenth-century city wall (Carmona and Ruiz 2011).

Occasionally the impact of flooding, silting and erosion could be devastating. Historical and topographical evidence shows that the east coast of Yorkshire (England) lost a dozen substantial villages and monastic granges to coastal erosion during the Middle Ages (Morris 1989, pp. 341-344), while further south the medieval port of Old Winchelsea now lies out in Rye Bay off the east Sussex coast (Martin and Martin 2004). Hard-won land could be lost in an instant as it was on the coast of north-western Germany where

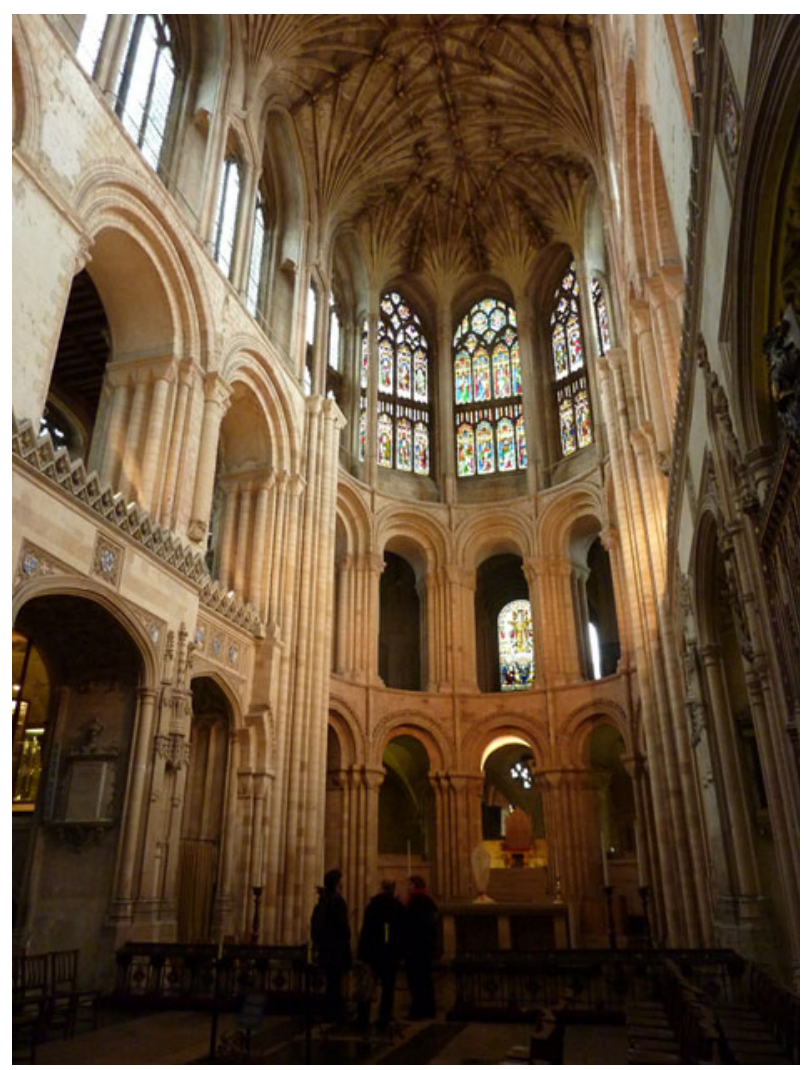

Fig. 4 The presbytery of Norwich cathedral. The lower two storeys largely survived the impact of the falling spire in 1362; the upper clerestory post-dates the 'hurricane' (1362-1369). The arcade level of the gallery was altered at the same time that the vault was constructed in c.1472-1499 (image copyright Steve Daniels. Licensed under Creative Commons Attribution-Share Alike 2.0 Generic Licence) 
archaeology, geology and palaeobotanical studies reveal the patient reclamation of salt marsh areas and their transformation into tidal flats after destructive storms in the North Sea (Fig. 5) (Meier 2004). Multiple case studies combine to indicate order-of-magnitude increases in soil-derived sediments on European floodplains between the eleventh and fourteenth centuries, perhaps partly the result of the laying out of new settlements and field systems. The silting and abandonment of mills, the loss of cultivated fields, the renewed construction of flood banks and the burial of earlier archaeological sites by alluvium are just some of the impacts noted (Keevill 1992; Lang and Bork 2006; Brown 2009; Macklin et al. 2010; Lewin 2010).

Long months of hot dry weather could be equally detrimental. Drought inhibited the growth of grass on pasture and affected dairy production and sales; on arable land, the hard ground increased expenditure on plough repairs and crops shrivelled in the sun. In Mediterranean Europe, there was insufficient rainfall to permit anything but the most tightly regulated irrigation. But for all those who lived in Europe's towns and cities, the greatest threat to life was fire, especially when fanned by strong summer winds. The wooden architecture and narrow streets of Bergen (Norway) facilitated seven major fires between 1170 and 1476 (Herteig 1959); most of the core of housing in Norwich (England) was destroyed in 1507, some 718 dwellings in all, and many other instances could be cited from Warsaw in Poland (1431) to Porto in Portugal (1491/1492; Tittler 1990; for a post1500 UK gazetteer see Jones et al. 1984). Europe's large religious buildings seem to have been especially vulnerable and many suffered repeatedly. At Chartres, most of the Carolingian cathedral was destroyed by fire in 1020, but there was damage again in 1134 and,

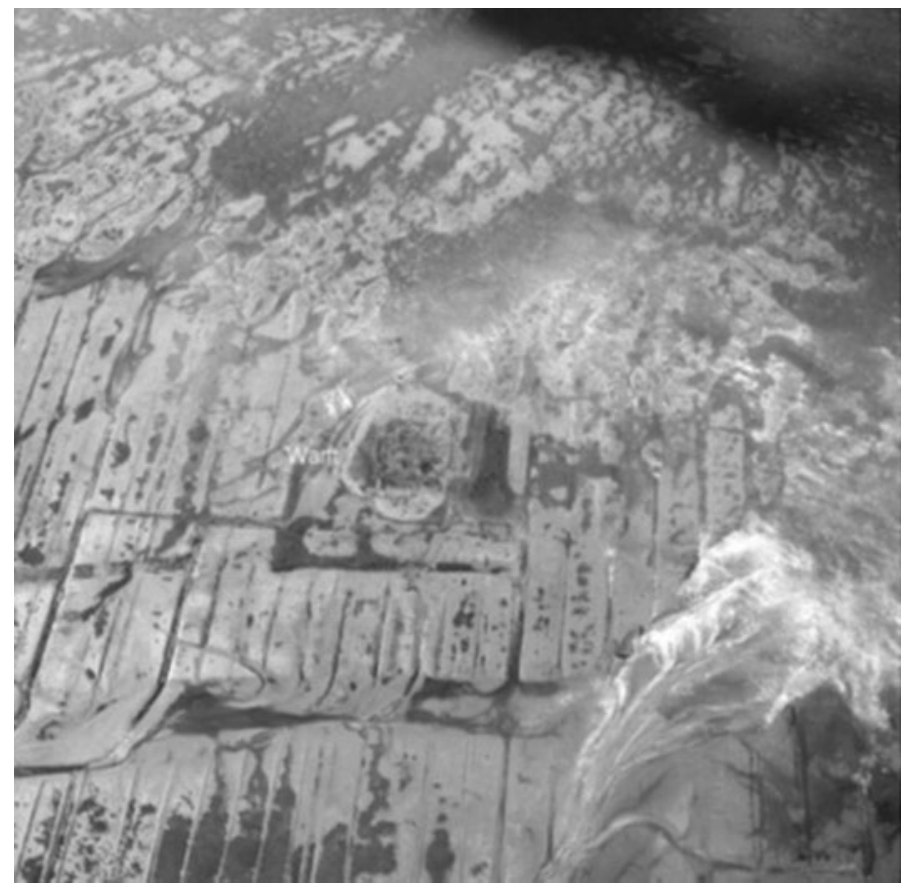

Fig. 5 Aerial photograph of a medieval Wurt and its surrounding field pattern in the present-day tidal flats in North Frisia, Germany. This farm land was drained, cultivated and protected by dikes, but lost again in the course of a catastrophic storm surge in 1362 (from Meier 2004, fig. 12) 
most seriously, in 1194; successive wooden steeples burnt down before 1507 (Miller 1996). Unsurprisingly, archaeological confirmation for fires is plentiful; at the church of St. Mark's in Lincoln (England), heat-distorted lead fragments were recovered within burnt debris $0.10 \mathrm{~m}$ thick, probably the result of a wider conflagration in 1122 (Gilmour and Stocker 1986).

\subsection{The cost of disasters in medieval Europe}

There is little doubt that the record for natural hazard events across Europe in the Middle Ages remains incomplete, such that a detailed analysis of continental-scale impacts is currently impossible. It is likely, however, that events with substantial loss of life are recorded. Based upon this, a figure of around a quarter to half a million deaths, excluding those from epidemics, seems to be the right order of magnitude for known events. This tally is over 500 years, however, and for a European population that oscillated between roughly 38.56 and 69.85 million (for these and other estimates see Malanima 2009), the levels of loss are quite modest. Losses from disasters in Europe were notably low compared with those in Asia and tended to inflict lower levels of loss on capital than elsewhere, allowing recovery from shocks that was surprisingly rapid. It has been argued that this may be a reason behind the economic rise of western Europe (Jones 1981). Those at greatest risk lived within the belts of seismicity in the Mediterranean, especially in the Italian city states which were among the largest and wealthiest cities in Europe at this time. The hazard-prone environments affected by hydrometrological risk along North Sea coasts should also be highlighted, particularly after the mid-thirteenth century. Curiously, casualties from rapid onset disasters in the later medieval period have not so far been identified in the archaeological record, though they have been claimed outside Europe (e.g. Korjenkov et al. 2006). A high proportion of victims were probably recovered, sometimes during search and rescue activities in the first 'golden' hours after the event. For example, six or seven people worked to pull survivors from collapsed buildings after the earthquake at Vera La Vieja in Almeria (Spain) in 1518, where perhaps 150 were lost (Olivera Serrano 1995, p. 46). Given that many of the survivors departed immediately, these figures may be questioned, and in the absence of reliable census information, there are always uncertainties about what percentage of the population may have perished. Tolls for individual events are generally measured in 10 s, sometimes 100 s (the earthquake at Baza in 1531 cost some 300 lives; Bertrand et al. 2000), although the effects were proportionally greater on a smaller medieval population. A few serious disasters were responsible for large losses of life-famine apparently caused by the volcanic explosion in 1258-1259 is said to have accounted for 15-20,000 in London alone (Keene 2011); earthquake-induced landslides in the Azores buried the settlement of Vila Franca do Campo in October 1522, killing 3-5,000 people (Silveira et al. 2003); while the March 1511 earthquake in Western Slovenia reportedly killed 12,000 people (Fitzko et al. 2005); and that in central Italy in December 1456 cost an estimated 70,000 lives (Guidoboni and Ferrari 2000). Disease epidemics took a much higher toll in both true and proportional terms, and in modern times, there is no comparator.

\section{Frameworks of hazard perception}

\subsection{The power of prayer and belief}

Across modern Europe, prayer remains a common response to hazard, though rarely a primary mechanism for the prevention of disaster (Mitchell 2003). In medieval Christian 
Europe, on the other hand, perceptions of natural events were frequently interpreted through readings of the Bible and devotional texts. Passages from the books of Genesis and Revelation, as well as the gospels, were especially formative and imparted through wall paintings, manuscripts, sculpture, stained glass, plays and pageants. Plagues, rains of fire, thunder and hail all figured prominently, and, according to Scripture, the death of Christ and the coming of the Apocalypse were both announced by earthquakes (Smoller 2000). Disaster and miracle could be intertwined so that, for example, at Wilsnack in Germany the site of a bleeding-host shrine was miraculously preserved after fire destroyed the village in 1383 (Zika 1988), while in Segovia (Spain) at the monastery of Santa María de los Huertos, a venerated carving of the Virgin is said to have 'appeared' just as the monastery was being swept away by floodwaters in 1304 (Bartolomé and Sánchez 1996). More generally, however, this and other disasters were 'Acts of God', a divine supernatural punishment for the sins of Man from which prayer, fasting and almsgiving might bring appeasement. At times of crisis, this narrative was energised through public display and special masses, as it was in 1315 when the English clergy processed barefoot after the failed harvest (Kershaw 1973) or in Cologne (Germany) in 1374 where the subsiding floodwater was attributed to the renewed devotion of its citizens (Rohr 2007). To prevent a repeat offence, sanctions were imposed to reinforce social norms, and these ranged from bans on over-indulgent celebration (Schenk 2007) to 'modesty regulations' imposed on indiscreet clothing and the wearing of jewels (Fäh et al. 2009; Schenk 2010).

Medieval Christian cosmology was by no means confined to formal liturgy. Priests said masses, charms and prayers over animals in the hope of warding off murrain (Jordan 2009) while consecrated candles and crosses of palm branches were burnt to ward off impending storms (Scribner 1984). Particular meaning might be attached to the weather on a saint's day (Cameron 2010, pp. 39, 65, 198) as well as to cryptic formulae thought to ward off sickness or sudden death. Among these were the religious invocations IHC/ IHS, the first three letters of Christ's name in Greek transliterated into the Roman alphabet (Fig. 6), the phrase Iesus Nazarenus Rex Iudaeorum, the Greek tetragramaton which refers to the four letters of the holy name for God in Hebrew, ananizapta as another name for God, and the pseudo Hebrew 'AGLA' (Atha Gebri Lielan Adonai/ 'Thou art mighty forever, O Lord'). These words held power if they were spoken or sung and even if they were eaten as prophylactic treatments (Cameron 2010, p. 54), and for this reason, they were also inscribed on medieval jewellery such as rings, brooches and pendants (e.g. Campbell 2009; Barroca 2011; Gilchrist 2012, pp. 272-273). As Duffy (1992, p. 283) has pointed out, charms like these reflect the most intimate anxieties of lay people.

A widespread belief in folk magic extended from echinoid fossils or 'thunderstones', which were believed to ward off thunder and lightning (Gilchrist 2008), to semiprecious stones such as agate or jasper. These and other materials such as organic gems (jet, coral), animal parts (badger claws, shell, bone), metals (pierced coins) and botanical specimens (chestnuts, acorns) were made up into amulets and prized for, among other things, protection during a bad storm (Bagnoli 2011, pp. 138-139). Some of these symbolic qualities crossed between cultures; the use of jet beads as a prophylactic amulet, and of glass bracelets imitating jet, is known from Christian, Muslim (here also as a 'Hand of Fatima') and Jewish contexts in later medieval Spain (Malalana Ureña 1997). Other talismans were highly specific to context; pages of the Koran sewn into the clothing of illiterate 'converted' Muslims in 16th century Spain were 


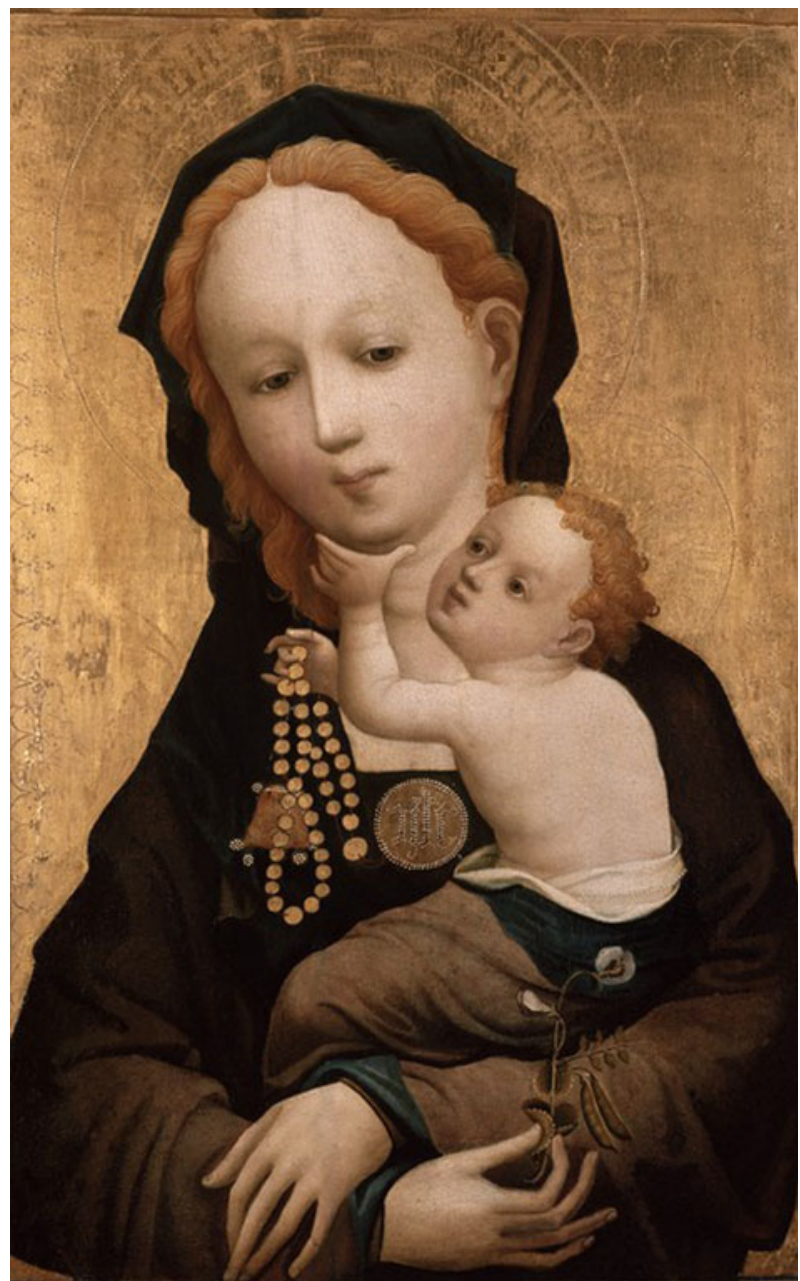

Fig. 6 The sacred monogram IHS, an abbreviation of Ihs Nazarenus, is found on 'devotional jewels' such as that worn by the Madonna in the panel painting of The Virgin and Child with Pea Blossom (c.1410) by the German painter Master of Saint Veronica. Devotion to the Holy Name was especially popular between the fourteenth and sixteenth centuries (Blake et al. 2003:176-188). (from farm6.staticflickr.com/5251/ 5471967545_2650f7c2d2_b.jpg)

thought to ward off illness and the devil, as well as being a covert sign of their outlawed faith (Surtz 2001).

However, a duality of beliefs of the origin of hazardous events was common, building upon the writings of Aristotle in Meteorologia, who taught that earthquakes were associated with the passage of wind passing into or out of the earth, or moving within it (Adams 1938, p. 506). Thus, 'natural causes' for hazards were commonly invoked in the Middle Ages, alongside a supernatural explanation. A key example is that of von Megenberg (1861, p. xxxiv), who in the fourteenth century wrote that:

Earthquakes arise from the fact that in subterranean caverns and especially those within hollow mountains, earthly vapours collect and sometimes these gather in such 
enormous volumes that the caverns can no longer contain them. They batter the walls of the caven in which they are and force their way into another and still another cavern until they fill every space in the mountain...If they cannot reach the surface they give rise to great earthquakes.

Puzzling happenings in nature were apt to be interpreted as divine forewarnings of extreme natural events (Walsham 2011, p. 346; Rohr 2007). Thus, in 1250 an earthquake in the Chilterns (England) was thought 'unusual' and 'unnatural' by Benedictine monk Matthew Paris and 'indicative of future events' while rough seas and floods in the same year were presaged by a swollen reddish moon (Vaughan 1986, pp. 260, 269). Similarly, an unfavourable juxtaposition of the planets was blamed for the Florence floods of 1333 (Schenk 2007) just as earthquakes as well as solar and lunar eclipses were all linked to the arrival of the Black Death (Cohn 2002, p. 229). In the latter case, Hippocrates' Epidemics informed these scholarly interpretations of natural philosophy; in this case, hot and moist Jupiter ostensibly encouraged ideal conditions for decomposition and plague caused by the noxious fumes released during earthquakes (Getz 1991).

Thus, 'scientific' explanations were not necessarily at odds with divine involvement (Smoller 2000), and a duality of views of a single event, involving both a natural and a supernatural explanation, was not uncommon. The continued role of both science and religion in modern society suggests that the situation is not as unfamiliar as might initially appear to be the case.

\subsection{The role of protective saints}

An alternative approach to 'risk management' was to call upon saints empowered to work the miracle of salvation. Thus, St. Barbara and St. Christopher could safeguard against sudden demise, while St. Scholastica protected against lightning strikes. All three might be described as 'universal' devotions and had a broad following (Cunningham 2005). However, because there was no chance of a confession, the prospect of an unexpected death was especially feared because earthly matters needed to be left in good order; there was a will to write and funeral arrangements to consider, as well as priests to be summoned for last rites. Although the Church permitted the confessions of the dying to be taken by a lay person, and assumed, in the absence of a confession, that peace had been made with God before death, it was thought that only bad people or non-Christians could die under such circumstances. On that basis, earthquakes could 'open and swallow' the pagans who resisted the teaching of St. Matthias (Ryan 1993) and drowning was perceived as "nonChristian' death, not least because Christ himself had walked on water (Daniell 1998, pp. 32-38, 71-75). In particular, death by lightning strike presented an insurmountable challenge. Not only was the identity of the victim specifically singled out and then widely publicised with claps of thunder, but there was absolutely no opportunity for the kinds of proper preparation for death associated with holiness. Local cults proliferated. In Bavaria, it was St. Magnus of Fussen who saved those caught in hail and lightning, and in Sicily, St. Agatha watched anxiously over volcanic eruptions; across Europe, many more came to be revered by the learned and illiterate alike (Jones 2003). In France alone, relief from drought could be pleaded from St. Godeberta of Noyon (near Amiens), St. Honorius of Amiens, St. Angadrisma of Beauvais, St. Solange of Bourges or St. Trophimus of Arles. The widespread availability of protective cults like these was in part a response to local experiences of environmental hazard and in part to the popularity of particular images and relics, so that 
each region accrued its own sacred history with or without papal approval (Bornstein 1986).

Veneration of saints took many forms; medieval wall paintings of St. Christopher were positioned opposite the lay entrance to English churches so that they could be seen immediately upon entering (Fig. 7) (Rosewell 2008, p. 72), church dedications such as those to St. John the Baptist, who could protect against hailstorms, are another evidence of loyalty, while the town of Sankt Florian in Austria is named after the popular St. Florian, who safeguarded against flood and fire in Central Europe (Atanasova Petkova 2012). For a ship's crew in peril, it was a pilgrimage that might be promised in return for rescue at a time of peril; 170 silver and 41 wax ships were among the votives left by pilgrims discharging their vows at the shrine of English saint Thomas de Cantilupe in Hereford

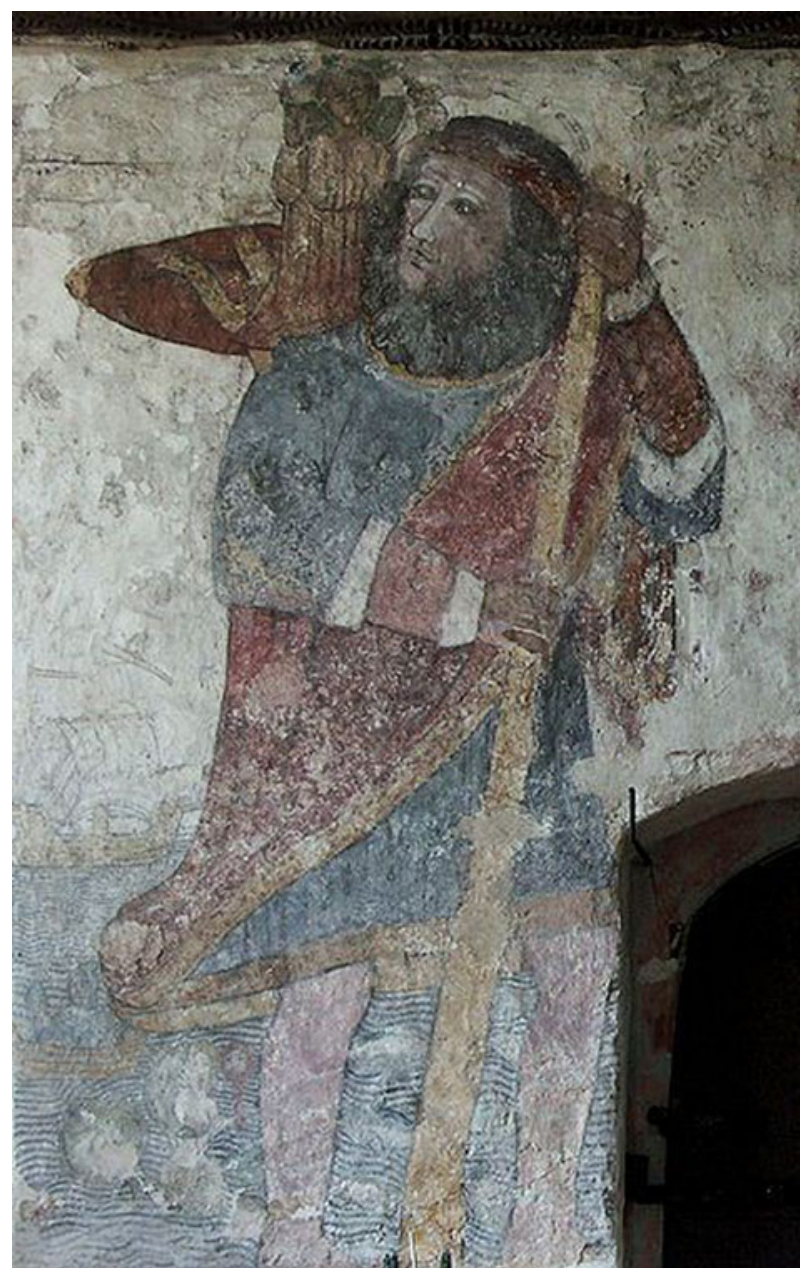

Fig. 7 Wall painting at St. Breaca's, Breage in Cornwall (England) showing St. Christopher carrying the Infant Christ on his shoulder. St. Christopher was one of the most popular saints in the medieval period. Whoever beheld his image was reasoned to be safe from sudden death that day (image from Wikipedia.org/ wiki/File:Breage_st_breca_005.JPG) 
Cathedral in the fourteenth century (Finucane 1995, p. 98). Pilgrim badges, pressed against a saintly shrine and then stitched onto clothing, provided visible testimony of these acts of pilgrimage, and, because of their talismanic quality, badges were embedded into church bells in Germany and Scandinavia to ward off bad weather.

\subsection{The use of relics}

Local relics were often activated when drought or epidemic threatened. At the Cistercian house of Fitero in Navarre (Spain), reliquary boxes were carried up the church tower to encourage clouds to form overhead during the summer months (Férnandez Gracia 2002). More commonly, relics and the Sacrament were paraded publically, as happened at Erice in western Sicily (Piervitali and Colacino 2001) or in Hanover where the relics of St. Waldetrude were processed (Cohn 2002, p. 75). When serious drought threatened in Barcelona, the bishop was rowed out into the harbour where he dipped the Holy Cross from the cathedral into the waters of the Mediterranean. As was often the case, public attention was guaranteed by bell ringing, chanting of the litany and the celebration of special Masses (Martín-Vide and Barriendos Vallvé 1995).

All these displays were orchestrated in response to a specific crisis, but more typically, rogationtide was the occasion for the processing of relics, sometime between late April and early June. In Spain, where the practice developed from the fifteenth century, these 'blessings in the fields' were generally 'pro pluvia' while in south Germany, Austria and Switzerland they protected against thunder and lightning (Zika 1988). In sixteenth-century Germany, the opening passages of the four Gospels were recited at local boundaries to
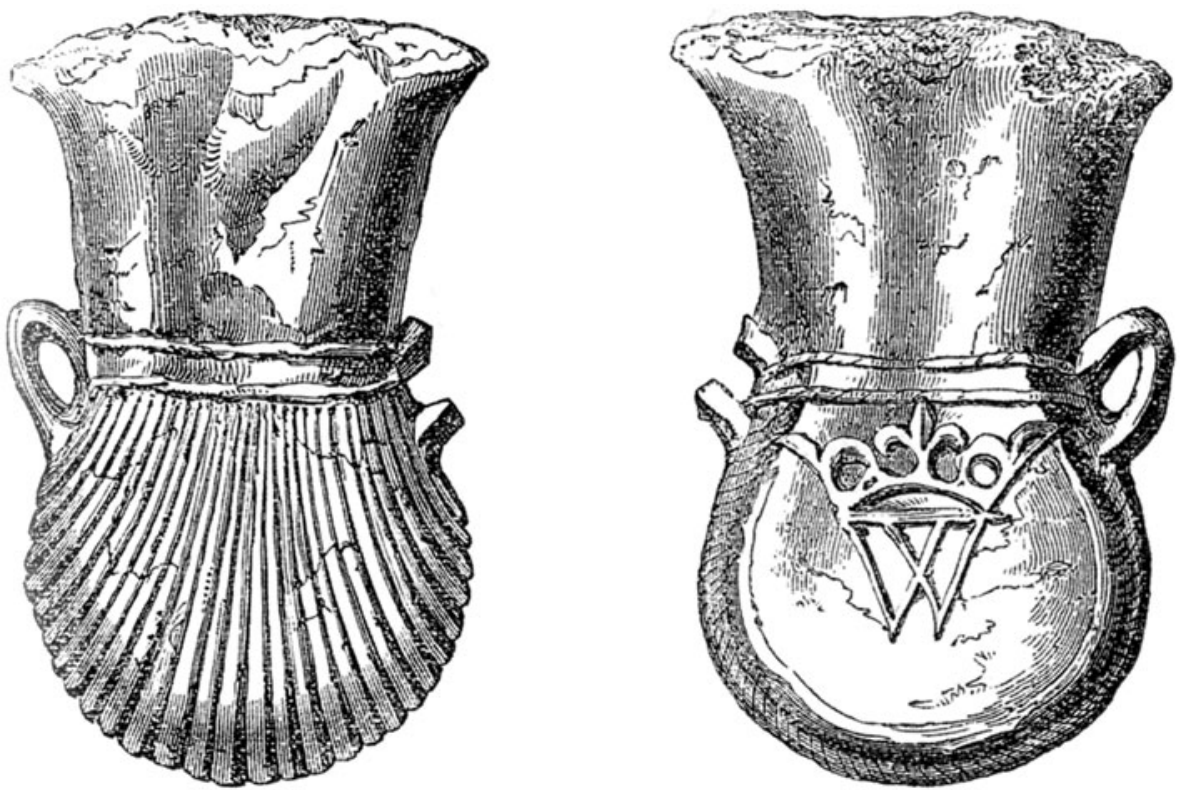

Fig. 8 A late medieval ampulla. This flask-shaped object combines shell decoration, a symbol of pilgrimage, with a monogrammed $W$. It is around $50 \mathrm{~mm}$ in height and, with its lugs for attachment, designed to be portable. This one may come from Walsingham (Norfolk, England) (from Hart 1864) 
protect against plague and damage to crops, while in England recent archaeological research on the distribution of finds of ampullae, miniature vessels containing water, oil and dust from shrines and holy wells suggests that they might have been ritually discarded in the fields as insurance against crop failure (Fig. 8) (Anderson 2010).

In summary, there is a side to the medieval mind that confounds the logic of modern risk management. Hazardous events were typically portrayed by the medieval Church as divine retribution, and, for that reason, appropriate acts of mitigation were developed to prevent similar behaviour reoccurring, such as addressing the questionable public conduct that may have summoned God's wrath. This attitude mirrors modern approaches to risk management in as far as an evaluation of the explanations for the event led to a developing range of mitigation options - in this case arguably a misdiagnosis for which the mitigation strategy was unlikely to be successful. However, medieval people also protected themselves from danger in ways not always favoured by the formal teachings of the Church, and the fact that they were apparently powerless to prevent a hazard happening did not stop them from trying to reduce the risk to themselves, as the next section to this paper demonstrates.

\section{Responding to disaster}

While medieval society as a whole relied more heavily on religion and devotion as a protection against environmental hazards than is the case today, proactive risk management was common too. Indeed, mitigation, protection and adaption, the three main categories of hazard-reducing practices today, were all applied during the Middle Ages (Smith and Petley 2009, pp. 72-101).

\subsection{Hazard mitigation}

Hazard mitigation, defined here as sustained non-structural actions taken to reduce or eliminate long-term risk to people and their property, was a familiar concept. Medieval communities could be proactive both in their management of environmental risks and while ensuring recovery from their longer-term effects. After the 1333 flood in Florence, the city authorities formed a committee to oversee the repairs, and they lowered taxes on imported foodstuffs and organised tax relief for those in need, facilitating the distribution of food supplies. Public services were restored by constructing a temporary bridge over the River Arno, and weirs and mills, thought to be to blame for the flooding, were banned close to the city (Schenk 2007). Measures of this sort, including structural assessments, financial relief and rehabilitation, were repeated in many other contexts (e.g. Kershaw 1973; Guidoboni and Ferrari 1995; Guidoboni and Ferrari 2000). During the course of the medieval period in London, there is evidence that responsibility for action moved away from the authority of the monarch towards the citizens themselves (Keene 2011), whereas in continental Europe civic authorities took a more central role.

A key aspect of risk mitigation in contemporary society is the sharing of potential costs, and cooperative and collective endeavour were a particular feature of medieval life. From the great households down to the most modest families, neighbours and friends exchanged gifts and engaged in acts of charity. When in 1318 the English king made a grant of alms to the Benedictine convent of Elstow, he did so 'out of compassion for the state of their house which is so greatly impoverished by the scarcity of the past years' (Kershaw 1973, p. 30). He might have added that to imitate Christ in the performance of charity was considered a most effective manner of attaining salvation. At other times, affected communities pleaded 
their own case when hard times befell them; the people of Mataró (Spain), for example, petitioned their bishop for a licence to collect alms for the repair of their churches after an earthquake struck in 1448 (Salicrúi Lluch 1995). In rural areas, manorial courts ensured that some modest resources were provided for villagers in need (Dyer 1989, pp. 234-257; Richardson 2005) while food alms were distributed by hospitals, direct from the dining tables of the wealthy, and as funeral bequests (Woolgar 2011).

All these charitable acts, large and small, provided relief in the event of misfortune but of far greater consequence were the fraternities and religious guilds that offered help inkind, loans or stipends to their members. Most of the urban population of later medieval continental Europe would have belonged to such a confraternity; in the mid-sixteenth century, Toledo boasted 143 groups for its 60,000 inhabitants, and they were quickly transformed into powerful and wealthy institutions through the many donations and bequests they received (e.g. Cossar 2001 for Italy; Flynn 1985 for Spain). The main purpose of a confraternity was to sponsor devotional activities and distribute charity to the poor in the form of cash, bread, wine and salt. Like the English king, this was the vehicle through which their members hoped to achieve personal salvation. In the case of individuals who had fallen on hard times as a result of shipwreck or storm damage, the confraternities did not offer to replace lost assets, but could draw upon funds to which members had previously contributed - a primitive form of social security (e.g. McRee 1993). This has some similarities to the modern business models of the reinsurance industry, which tries to ensure that premiums will balance insurance pay-outs over long periods of time, with profit being generated primarily through investment return between disasters. Interestingly some confraternities continue to exist today-for example, the Archiconfraternity of the Misericordia, which was founded in Florence in 1244, remains a key civilian protection force in Italy.

Rather than sharing economic loss across the community, another important principle was to spread the burden of loss over a longer period in order to reduce its immediate severity. Across medieval Europe, very large barns on monastic estates provided centralised storage for unthreshed grain (Brady 1997), while supplies of threshed grain were piled in cellars and upper storeys as well as in civic granaries. Margins were tight and quantities insufficient to ride out a long crisis (Claridge and Langdon 2011), but localised shortfalls could be overcome temporarily by releasing a portion of what was held in store. An alternative, if costly, strategy was to purchase grain from outside the local area. For example, in the winter of 1316 English merchants travelled far afield to buy up stores of corn, and even went abroad (Kershaw 1973). This option was favoured too when impacts were geographically widespread and demand could not be met locally, for example after the volcanic eruption of 1258-1261 when grain was shipped from Germany and Holland into London (Stothers 2000). Episodes like these were easily exploited and, to prevent this, merchants were prohibited from buying and reselling the corn (Keene 2011). In later centuries too, there were those who envisaged permanent stockpiles of grain to be sold without thought to profit. The Leadenhall granary, built in the 1440s in London, was one such project designed to make the capital less sensitive to famine (Samuel 1989).

\subsection{Hazard protection}

Hazard protection, used here to describe structural responses designed to reduce risk, is also well documented for the medieval period. In the case of flooding, floor levels inside buildings could be raised, as excavation proved in the transept of the abbey church at Bordesley Abbey in Redditch (England; Rahtz and Hirst 1976, pp. 70-72). At the 
monastery of Clara-a-Velha in Coimbra (Portugal), the flooding from the nearby River Mondego was so frequent after 1330 that the nuns were forced to raise the interior levels of their monastic buildings repeatedly, eventually having to construct a unique elevated storey inside their church (Fig. 9) before finally abandoning the site in 1677 (Cunha et al. 2000). Other kinds of investments too needed protection from floodwaters. At Romney Marsh on the coast of southern England, Canterbury Cathedral Priory invested in sea defences and buildings to protect both its livestock and the soils so studiously improved with leguminous crops and dressings of lime and manure (Gross and Butcher 1995). Archaeological features here and elsewhere range from large-scale engineering such as embankments and windpowered pumping engines (especially in the Netherlands) to more minor projects such as the walls, sluices and ditches sometimes picked up by archaeological earthwork and contour surveys (e.g. Chapman 2010, pp. 147-148).

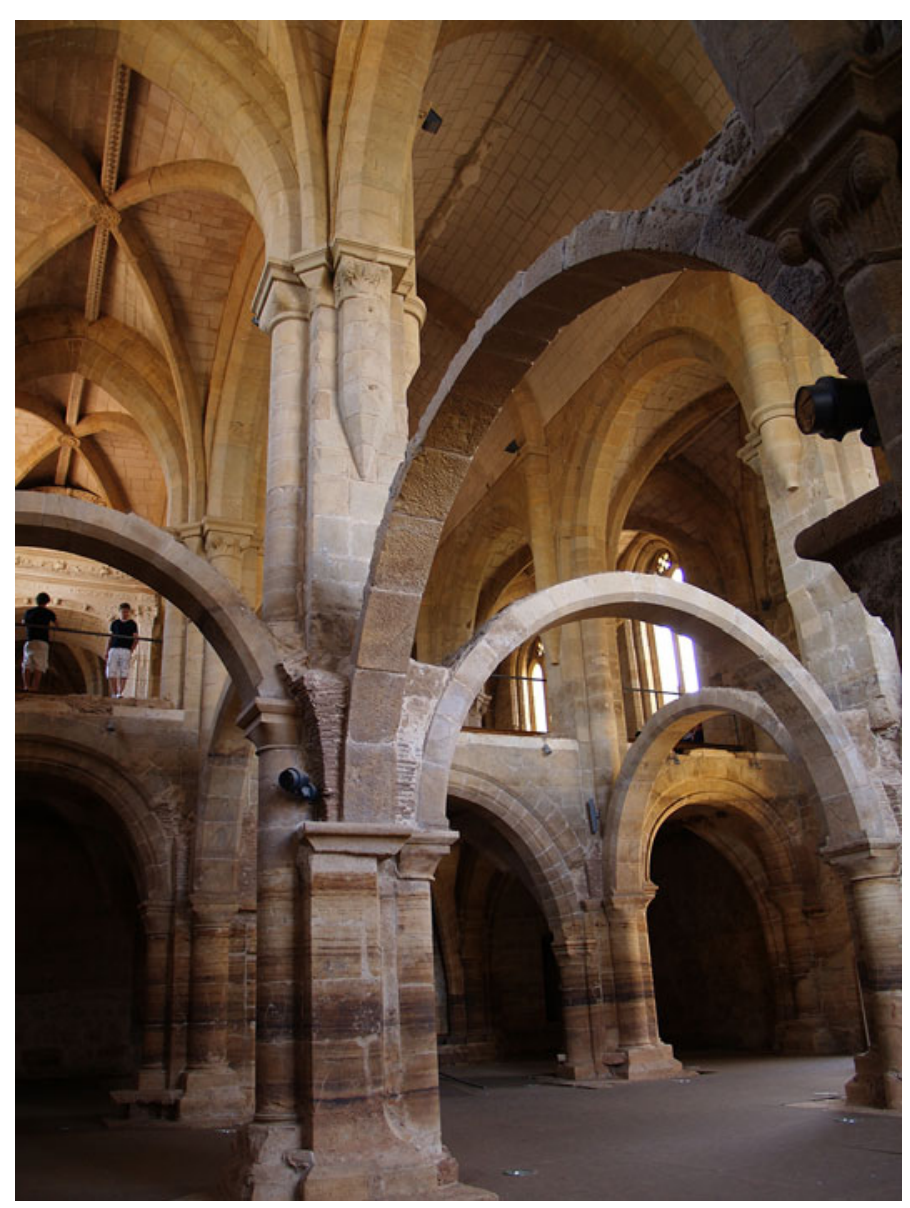

Fig. 9 The interior of the monastic church at Clara-a-Velha in Coimbra (Portugal). To escape the floods from the nearby River Mondego, the nuns raised the floor of their church and finally built an upper storey to span its full length. Once they had relocated their altars, the celebration of Mass could continue. Here, people are seen on the partially reconstructed upper storey, and the staining from high water levels is visible on the supporting columns below (picture courtesy of Alejandra Gutiérrez) 
When rebuilding took place after a disaster, structural modifications were sometimes introduced. The ninth-century town wall at Andújar (Spain) was remodelled and reinforced after the 1170 earthquake (Peláez et al. 2005), while excavation in SW England at the church of St. Michael on Glastonbury Tor revealed that rock fissures had been blocked up with mortared material when the church was rebuilt after being flattened in an earthquake in September 1275 (Rahtz 1970). Disaster could open up opportunities for investment and rebuilding, even lay down a statement of confidence, but vested interests invariably led owners to disregard the prospect of further calamities (Ambraseys 2006), particularly when hazards were deemed to be preventable. Such optimism could be wildly misplaced; thousands of hectares of reclaimed marshland were lost along the Thames Estuary in the later medieval period, for example, while the inundation of $300 \mathrm{~km}^{2}$ of embanked land south of Dordrecht (Netherlands) in 1421-1424 was blamed on a lack of dike maintenance and specifically on peat extraction (Galloway and Potts 2007; Gottschalk 1975). Maintenance, it seems, had been neglected. For a variety of reasons, people living in vulnerable areas could undoubtedly underestimate the risk of major events or the effectiveness of their protection. In other cases, they showed extraordinary resilience. Excavations at Kootwijk (Veluwe, the Netherlands) provide telling evidence of the defiance of villagers as they fought against drifting sand by erecting long screens $(>100 \mathrm{~m})$ to prevent their fields and settlements being smothered (Heidinga 1987; van Doesburg 2009). When wind-blown sand overwhelmed settlements, it led to rebuilding further and further inland. The original church at Kenfig in south Wales was replaced in 1262 and a third built in a safer location at the end of the fifteenth century (Morris 1989, p. 340).

\subsection{Hazard adaptation}

Adaptation to hazards involves a change of behaviour so that a risk can be tolerated and the timely identification of hazards is central to this. When the tower houses of Pisa were destroyed in a fire in 1158 , the civic authorities sought to minimise further risk by ordering the demolition of wooden porches and balconies that had contributed to the fire spreading. Elsewhere in Italy chimneys were to be built out of brick by the mid-fourteenth century, thatch was to be substituted with non-flammable tiles, and it was forbidden to store large quantities of combustible products; precautionary measures like these could be found in many countries (Tragbar 2006; Jack 1979). In England, the investigation of incidents of flooding along the Thames estuary fell to royal commissions which were made up of local landowners and court officials; some 153 operated between 1280 and 1449 reacting to concerns voiced over the condition and organisation of coastal or river defences (Galloway and Potts 2007). In those regions where environmental hazards were a regular occurrence, there was greater community preparedness. In the Netherlands, both Holland and Utrecht had developed centralised mechanisms to manage their dike systems before 1250 , a solution that was encouraged by an unusual set of circumstances; the disproportionately high maintenance and repair costs combined with a fragmented pattern of landholding required fuller coordination of responsibilities (Tol and Langen 2000).

Nevertheless, when disaster hit, if the threat was sudden, temporary and localised, risk judgements had to be intuitive and immediate. Thus, Florentines escaped the 1333 floods by climbing onto the roofs of their houses (Schenk 2007), while in Trieste the citizens climbed the slopes of San Giusto to avoid the tsunami that followed the West Slovenia earthquake in 1511 (Tinti and Maramai 1996). Sometimes, there was help from others, so that in Lucca (Italy) in 1346 carpenters, stonemasons and bricklayers were required to demolish houses to prevent urban fires spreading (Tragbar 2006). In the aftermath, many 
were forced to look to their own devices, reducing the size of their households, or selling possessions and land in order to raise money for the purchase of essential foods (Keene 2011). Some moved away like the inhabitants of Vera La Vieja who decamped into nearby fields after the 1518 earthquake. They were responding, as many others did at other times and places, by temporarily shifting down to subsistence levels and saving their lives. Sometimes a minor relocation like this could develop into something more permanent and thereby modify the morphology of a settlement, as happened in flooded villages along the fen margin of East Anglia (England) when fourteenth-century manor houses were relocated uphill (Ravensdale 1974). But some disasters also encouraged more permanent migration. If the impact was widespread, as it was in the case of the Black Death, there were new opportunities for employment and better housing, and so people moved to take advantage. Siena and Orvieto (Italy) were not alone among civic authorities in passing emergency legislation to restrict population movements (Cohn 2007). In the case of rapid onset events such as floods or earthquakes, where the effects tended to be more localised, the devastation was rarely total or so widespread. Nevertheless, archaeology does provide some case studies of new settlements laid out after disasters (e.g. Taylor 1983, p. 171), one of these is New Winchelsea (England) which was laid out in its present hilltop location after two great storms in 1250 and 1252 breached the shingle barrier on which the port of Old Winchelsea once stood (Martin and Martin 2004). Another example is Vera La Vieja where not one of the 200 houses remained standing after the earthquake of 1518. A contemporary assessment of conditions at the site cites the difficulties of building solid foundations for housing, the poor condition of the castle, the cost of clearing rubble, the drying up of water from the spring, and the vulnerability of the defenceless survivors to North African raiders (Olivera Serrano 1995, p. 55). For these reasons, the survivors were eventually moved from their temporary encampments to a new site nearby complete with 140 new houses, church, bakery, square and town walls (Villanueva Muñoz 1986-1987).

Even when living conditions were deteriorating, archaeological studies show that settlements could still flourish and everyday activities might even intensify, as they did in transhumant and mining communities in the French Alps during the onset of the 'Little Ice Age' (Walsh 2005). The lesson is that notions of risk are contingent on time and place and other factors were often in play when the survivors of disasters were permanently relocated. For example, it was unfavourable economic conditions that hampered the recovery of Syracuse in the two decades following an earthquake in 1542 (Boschi et al. 1995). Likewise, the archaeological evidence from England suggests that there was no direct or exclusive link between settlement desertion and disaster, whether that be plague or climatic deterioration (e.g. for Hound Tor and the climate debate, see Beresford 1979; Wright 1976; Austin and Walker 1985; Allan 1994). Several interrelated causes were usually to blame, such as weakening demographic pressure (Astill and Davies 1997, pp. 149-150 for Eastern Brittany in the fifteenth century) or tenurial circumstances (Taylor 1983, p. 199). Unless the landscape was dramatically altered, as it might be after a landslide, subsistence agriculture was usually able to continue, and people stayed where they were. Even when medieval Sicilians living on the flanks of Mount Etna were repeatedly threatened by volcanic eruptions and earthquakes, their ruined settlements were invariably rebuilt on the same site or close by (Chester et al. 2005). At Shipston-on-Stour in Warwickshire (England), nearly two-thirds of the town was destroyed in a fire in 1478, but as the records of Worcester Cathedral show, the town was rebuilt within 5 years and its trade flourished (Dyer 1992/1993). This is not dissimilar to modern responses to risk, in which people remain generally unwilling to relocate even where the levels of hazard demonstrably exceed levels that are considered to be tolerable under normal circumstances. Alexander 
(1991) describes such geographical inertia as a key response to risk in modern societies, even where no mitigation is available or practicable.

Aside from these direct responses to disaster, several traditional features of the medieval agrarian and household economy across Europe served to buffer risk, particularly from routine 'slow-onset' hazards such as harvest failures. Diversification was one answer, for example planting vegetables and fruit in domestic gardens (Harvey 1981), an activity for which there may be archaeological evidence in the form of land parcels, intensive manuring, hand dug furrows and plant remains (e.g. for Cookstown, Co. Meath, Ireland; Murphy and Potterton 2010, p. 353). A judicious mix of crops also reduced the risk of failure; for example rye, barley and oats were planted as well as wheat, which itself came in different varieties (rivet, bread, etc.). The consumption of 'fall-back foods' represents a second form of diversification, and in the eleventh century, these varied from roots to herbs and even natural clays mixed with a little flour to make bread (Le Goff 1978, pp. 22-23). In the Mediterranean, it was the chestnut which provided an inferior type of flour for bread (Delano Smith 1979, pp. 215-217). Elsewhere, crops were selected to cope with environmental stresses (oats in $\mathrm{N}$ Europe, for example, were less affected by excessive rainfall), and in some lowland areas, the deliberate scattering of arable strips across different soils helped to share the risks of a poor harvest across the whole community (e.g. Fenoaltea 1975; McCloskey 1991; Cosgel 1990; Bekar and Reed 2003).

Other means of buffering risk was to intensify land use; for example, the careful management of woodland could create a renewable resource, and crop rotations on arable land acted to rest the soil. These practices enabled the medieval farmer to extract more from existing areas of agricultural exploitation. Archaeology also reveals how medieval communities shared their landscapes. The way in which administrative territories were shaped to converge on valuable resources such as woodland or pasture is one example, albeit with earlier origins (Aston 1985, pp. 42-43). Another is the sharing of water in arid environments; in parts of medieval Spain, villages were dependent for their agrarian water supply on a network of hydraulic or gravity-flow canals whose administration depended wholly upon cooperation between upstream and downstream irrigators (e.g. examples in Kirchner 2010; Gerrard 2011). At the same time, pressure on food resources could also be alleviated by extending the zone of cultivation and the reclamation and transformation of coastal wetlands and the drainage of freshwater backfens are well documented during the Middle Ages by landscape archaeologists in north-west Europe (Rippon 2000, 2004). Recolonisation intensified during the twelfth and thirteenth centuries, for example in north Holland and in newly embanked areas such as the German marshes. The construction of sea walls and fen banks, the digging of artificial channels and canals for drainage, and the establishment of villages, farmsteads and granges were all part of this process. Paradoxically, extensification in reclaimed coastal areas also played a major role in putting medieval communities at risk.

\section{Discussion}

\subsection{The costs of environmental hazards}

As with modern environmental hazards, the impact of a disaster was controlled by a range of interacting factors. Modern analogues show that structurally weak buildings, especially those constructed from masonry, tend to perform poorly during earthquake shaking (Smith and Petley 2009), and in some cases, it was the poor standard of medieval construction that 
turned hazard into disaster. Contemporary accounts of the 1303 Crete earthquake and tsunami describe houses 'collapsed from their foundations' and churches, castles and the towns walls, all presumably of stone, were severely damaged (Guidoboni and Comastri 1997). Typically, it was also the low frequency high-magnitude events that generated higher losses, at least in part because preparedness was low. However, there was a strong element of serendipity too. For example, there were higher casualties in the Azores in 1522 because the earthquake struck $2 \mathrm{~h}$ before dawn when people were sleeping inside buildings which then collapsed or were buried. The chaos that ensued from events like this also provided the opportunistic with unexpected possibilities for personal gain. There were complaints of pillaging after the Vera La Vieja earthquake in 1518 (Olivera Serrano 1995, p. 49), and, when the earthquake and tsunami struck Crete in 1303, the Greek populace took advantage of the disorder to begin looting, a measure of their discontent under Venetian rule (Guidoboni and Comastri 1997). Just as disaster could reinforce public confidence if mitigation, protection and adaption measures were successful, so it momentarily removed social constraints and could undermine trust in existing authority, enhancing the possibilities of confrontation (e.g. Keene 2011). In effect, disaster could act as a catalyst for social change, although the degree to which this was the case remains unclear.

The costs of a disaster were often severe and lasting. Tsunamis, for example, required reconstruction of damaged coastal infrastructure and shipping over many years; flooding in Florence in 1333 cost around 300 lives, but it also left collapsed bridges and houses, mudchoked streets, dead cattle and ruined provisions (Schenk 2007). The monetary costs of reconstruction might be met through a combination of direct injections of capital from the state, national taxation schemes and benefits for the local population in the form of tax relief and renewed privileges during the rehabilitation period, often with the aim of preventing emigration. Exposure to risk increased when several events occurred in quick succession, especially when different sectors of the agricultural population were affected. The agrarian crisis of 1315-1322 was one of these, a period when the Netherlands, for example, is estimated to have lost 5-10\% of its population to severe floods in 1313 and 1315 and the famine of 1314-1317 (Tol and Langen 2000; Newfield 2009). Recurring shortages of food brought malnutrition, infection and infant mortality (Campbell 2010). In England, a pronounced decline in construction work on churches, cathedrals and monasteries has been noted in this period, together with disuse and desertion of settlement (Dyer 2010).

\subsection{Complexity and natural hazards in medieval times}

Smith and Petley (2009) characterise contemporary natural hazard risk as an emergent property arising from complex interactions between societies and the natural environment. Thus, disasters are not the result of an external forcing on an unprepared population, but instead emerge from the ways in which hazardous processes interact with people through time and across space. Risk from natural hazards in medieval times shared exactly these characteristics. Natural disasters were not external agents to which medieval communities reacted; they were social constructions (essays in Quarantelli 1998).

Medieval people had a broad conception of environmental hazards. This embraced uncertainty and fear of harm, but also containment and control; it should not be assumed that medieval society as a whole was passive or unable to cope with natural disaster, nor that attitudes to risk were static or simple. We note, in particular, a tension between individual and collective responses, on the one hand spiritual and superstitious, and on the 
other pragmatic with choices and mitigating adjustments that were surprisingly alike (Smith and Petley 2009, p. xxiii). These risk-sensitive 'tactics' of medieval Europe shared much in common with prehistoric communities (and indeed non-human organisms; Winterhalder et al. 1999) as well as other 'agricultural' societies (e.g. Halstead and Jones 1989). We can also detect a contrast between responses to catastrophic unheralded events and more regular, known threats such as flooding. Greater resilience was to be found in communities frequently exposed to natural hazard and who then evolved more sophisticated coping skills and organisational accomplishments. This has been noted previously in regions prone to flooding (Mauelshagen 2007) and among so-called 'seismic cultures' with long experience of earthquake damage (Caputo and Helly 2008). However, different sections of society also adjusted differently. Medieval merchants, for example, spread their personal risk by entering into partnerships, dividing cargo over several smaller craft, and allowing third parties to buy shares in their ships. Once there was a division between the sedentary merchant, his carrier and his agent, insurance was needed for goods that were out of sight, on the move and subject to all kinds of perils from shipwreck to piracy. Marine insurance, as we would understand that term, probably dates to the first half of the fourteenth century, much of the evidence for policies coming from Genoese, Pisan, Florentine and Venetian merchants (Spufford 2002, pp. 30-34). And by the end of the Middle Ages, Dutch households were already countering financial risk by making investments in capital markets as a means of securing surplus income (Zuijderduijn and De Moor 2011). Agrarian decisions, by contrast, were generally more likely to be 'risk-averse', perhaps because of the broader community involvement and the obvious consequences of risking too much.

In order to explain and understand natural hazards, medieval people drew upon a confection of theology, popular enthusiasms and contemporary scientific philosophy. As we have seen, the assumption of divine judgement could be a powerful motivator of responsible action when it came to helping the less fortunate. The Church explicitly stressed charity as a means of spiritual sanctification. Six of the seven 'acts of mercy' taught as a regular part of medieval religious education, and frequently represented in church painting and sculpture, were feeding the hungry, giving drink to the thirsty, clothing the naked, visiting the sick, lodging the homeless and burying the dead-all important formula for behaviour in the aftermath of natural disaster (Flynn 1985). This is one reason why responses to the different types of hazard described here seem remarkably similar. However, while Christian interpretations might be literal and moral, they could also be allegorical and mystical (Bartlett 2008); in spite of the central importance of the Church, medieval people did not act with one voice (Abou-El-Hai 1991). In that sense, disasters are fascinating windows onto medieval society. As one author has expressed it 'we cannot be just students of disaster. We must first be students of society and culture' (Oliver-Smith 1986, p. 25).

\section{Conclusions}

Medieval Europeans were constantly exposed to a broad range of environmental hazards, and geographers, archaeologists and historians are well placed to contribute to their study, not only in resolving the dating, scale and frequency of events but also in assessing the human response. There is considerable room to expand these enquiries, both in deepening and broadening fieldwork practice, and in developing our analysis beyond outstanding events and their immediate consequences. It is already clear, however, that risk in the past was not always imposed by external forces, as some have claimed. Instead, communities 
sometimes put themselves at risk or were placed at risk by those who sought economic gain through the alteration of their environments; thus, human agency was central to creating and mitigating risk. Above all, we should banish the popular public image of the medieval period as a time of superstitious hysteria and hopelessness. In many senses this too was a 'risk society', one with an increasingly sophisticated toolkit in hazard mitigation and adaption and developing measures of protection. Specific measures taken to manage the risk of flooding in the Netherlands, emergency relief from flood events in Italy and reconstruction after earthquakes in Spain are especially striking. Throughout this period, faith was no barrier to mitigation, and although medieval society may not have been the best protected against environmental hazards or the best resourced or claim a complete understanding of the risks it faced, it was also perhaps not the most frightened.

Acknowledgments This paper is the fruit of collaboration through the Institute of Hazard, Risk and Resilience at the University of Durham. CMG would particularly like to acknowledge advice from Christopher Dyer, Alejandra Gutiérrez, Nick Watson and Sarah Semple during the preparation of this paper and to recognise the influence and inspiration of structural geologist Paul Hancock (1937-1998). DNP's work on this paper was supported by NERC/ESRC grant NE/J01995X/1 (Earthquakes Without Frontiers: a partnership for increasing resilience to seismic hazard in the continents) and seeks to acknowledge the inspiration provided by Robert Howard.

Open Access This article is distributed under the terms of the Creative Commons Attribution License which permits any use, distribution, and reproduction in any medium, provided the original author(s) and the source are credited.

\section{References}

Abou-El-Hai B (1991) The audiences for the medieval cult of saints. Gesta 30(1):3-15

Adams FD (1938) The birth and development of the geological sciences. Bailliere, London, p 506

Alexander D (1991) Natural disasters: a framework for teaching and research. Disasters 15:209-226

Allan JP (1994) Medieval pottery and the dating of deserted settlements on Dartmoor. Proc Devon Archaeol Soc 52:141-147

Ambraseys NN (2006) Earthquakes and archaeology. J Archaeol Sci 33:1008-1016

Anderson W (2010) Blessing the fields? A study of late-medieval ampullae from England and Wales. Med Archaeol 54:182-203

Astill GG, Davies W (1997) A Breton landscape. UCL Press, London

Aston MA (1985) Interpreting the landscape: landscape, archaeology and local history. Batsford, London

Atanasova Petkova G (2012) Studies of names of saints (Latin by origin), protecting people from natural disasters and during difficult situations. Speech Context 1(IV):118-122

Austin D, Walker MJC (1985) A new landscape context for Houndtor, Devon. Med Archaeol 29:147-152

Bagnoli M (2011) The stuff of heaven. Materials and craftsmanship in medieval reliquaries. In: Bagnoli M, Klein HA, Mann CG, Robinson J (eds) Treasures of heaven. Saints, relics, and devotion in medieval Europe. British Museum Press, London, pp 137-147

Bailey M (1991) Per impetum maris: natural disaster and economic decline in eastern England, 1275-1359. In: Campbell BMS (ed) Before the Black Death. Studies in the crisis of the early fourteenth century. Manchester University Press, Manchester, pp 184-208

Baillie M (2006) New light on the Black Death: the cosmic connection. Tempus, Stroud

Barroca MJ (2011) A medieval prayer finger ring from São João de Tarouca (Portugal). In: Carver M, Klapste J (eds) The archaeology of medieval Europe. Twelfth to sixteenth centuries, vol 2. Aarhus University Press, Aarhus, pp 432-433

Bartlett R (2008) The natural and the supernatural in the Middle Ages. Cambridge University Press, Cambridge

Bartolomé B, Sánchez C (1996) Nuestra Señora de las Aguas, una olvidada advocación segoviana. Estudios Segovianos 37:153-170

Beck U (1992) Risk society: towards a new modernity, vol 17. Sage, London

Bekar CT, Reed CG (2003) Open fields, risk and land divisibility. Explor Econ Hist 40:308-325 
Bell WT, Ogilvie AEJ (1978) Weather compilations as a source of data for the reconstruction of European climate during the medieval period. Clim Chang 1:331-348

Benito G, Machado MJ (1998) Palaeoflood hydrology of the Tagus River, Central Spain. In: Benito G, Baker VR, Gregory KJ (eds) Palaeohydrology and environmental change. Wiley, Chichester, pp 317-333

Beresford G (1979) Three deserted medieval settlements on Dartmoor: a report on the late E. Marie Minter's excavations. Med Archaeol 23:98-158

Bertrand M, Pérez Cruz M, Sánchez Quirante L (2000) Los baños árabes de Baza. La intervención de urgencia de apoyo a la restauración. Anuario Arqueológico de Andalucía III(1):598-616

Blake H, Egan G, Hurst J, New E (2003) From popular devotion to resistance and revival in England: the cult of the holy name of Jesus and the Reformation. In: Gaimster D, Gilchrist R (eds) The archaeology of Reformation 1480-1580. Maney, Leeds, pp 175-203

Bornstein D (1986) The shrine of Santa Maria a Cigoli: female visionaries and clerical promoters. Mélanges de l’Ecole Française de Rome. Moyen-Age, Temps modernes T. 98, Nº1, pp 219-228

Boschi E, Guidoboni E, Mariotti D (1995) Seismic effects of the strongest historical earthquakes in the Syracuse area. Ann Geophys 38:223-253

Boschi E, Guidoboni E, Ferrari G, Mariotti D, Valensise G, Gasperini P (2000) Catalogue of strong Italian earthquakes from 461 AC to 1997. Ann Geophys 43(4):815-834

Brady N (1997) The gothic barn of England: icon of prestige and authority. In: Smith EB, Wolfe M (eds) Technology and resource use in medieval Europe: cathedrals, mills and mines. Aldershot, Ashgate, pp 76-105

Brady N (2004) Archaeological investigation and excavation. John's Bridge, Kilkenny. River Nore flood alleviation scheme. Unpublished typescript report 01E0036. The Archaeological Diving Company Ltd

Brázdil R (1998) The history of floods on the rivers Elbe and Vltava in Bohemia. Erfurter Geogr Studien 7:93-108

Brázdil R, Pfister C, Wanner H, Von Storch H, Luterbacher J (2005) Historical climatology in Europe-the state of the art. Clim Chang 70:363-430

Briffa KR, Jones PD, Schweingruber FH, Osborn TJ (1998) Influence of volcanic eruptions on northern hemisphere summer temperatures over 600 years. Nature 393:450-455

Brown AG (2009) Colluvial and alluvial response to land use change in Midland England: an integrated geoarchaeological approach. Geomorphology 108:92-106

Cameron E (2010) Enchanted Europe. Superstition, reason, and religion, 1250-1750. OUP, Oxford

Campbell M (2009) Medieval jewellery in Europe 1100-1500. Victoria and Albert Museum, London

Campbell BMS (2010) Nature as historical protagonist: environment and society in pre-industrial England. Econ Hist Rev 63(2):281-314

Camuffo D, Enzi S (1996) The analysis of two bi-millenary series: Tiber and Po river floods. In: Jones PD, Bradley RS, Jouzel J (eds) Climatic variations and forcing mechanisms of the last 2000 years. Springer, Berlin, pp 433-450

Caputo R, Helly B (2008) The use of distinct disciplines to investigate past earthquakes. Tectonophysics 453:7-19

Carmona P, Ruiz JM (2011) Historical morphogenesis of the Turia River coastal flood plain in the Mediterranean littoral of Spain. Catena 86:139-149

Chapman A (2010) West Cotton, Raunds. A study of medieval settlement dynamics AD 450-1450. Excavation of a deserted medieval hamlet in Northamptonshire, 1985-1989. Oxbow, Oxford

Chester DK, Duncan AM, Guest JE (2005) Responses to eruptions of Etna from the classical period to 1900. In: Balmuth MS, Chester DK, Johnston PA (eds) Cultural responses to the volcanic landscape. The Mediterranean and beyond. Archaeological Institute of America, Boston, pp 93-107

Ciccarello S (1996) A short note on some Arabic inscriptions recording seismic effects in the Mediterranean area 472 H./1079 AD-703 H./1303-1304 AD. Ann Geophys 39(3):487-491

Claridge J, Langdon J (2011) Storage in medieval England: the evidence from purveyance accounts, 1295-1349. Econ Hist Rev 64(4):1242-1265

Cohn SK (2002) The Black Death transformed: disease and culture in early renaissance Europe. Arnold, London

Cohn SK (2007) After the Black Death: labour legislation and attitudes towards labour in late-medieval Western Europe. Econ Hist Rev 60(3):457-485

Connell B, Gray Jones A, Redfern R, Walker D (2012) A bioarchaeological study of medieval burials on the site of St. Mary Spital: excavations at Spitalfields Market, London E1, 1991-2007. Museum of London Archaeology, London

Cosgel MM (1990) Scattering and contracts in medieval agriculture: challenges ahead. J Econ Hist 50:663-668 
Cossar R (2001) The quality of mercy: confraternities and public power in medieval Bergamo. J Mediev Hist 27(2):139-157

Cunha E, Fily M-L, Clisson I (2000) Children at the convent: comparing historical data, morphology and DNA extracted from ancient tissues for sex diagnosis at Santa Clara-a-Velha (Coimbra, Portugal). J Archaeol Sci 27:949-952

Cunningham LS (2005) A brief history of saints. Blackwell, Maldon

Daniell C (1998) Death and burial in medieval England 1066-1550. Routledge, London

Dawson AG, Hickey K, Mayewski PA, Nesje A (2007) Greenland (GISP2) ice core and historical indicators of complex North Atlantic climate changes during the fourteenth century. Holocene 17(4):427-434

Delano Smith C (1979) Western Mediterranean Europe. Academic Press, London

Dominey-Howes D (2002) Documentary and geological records of tsunami in the Aegean Sea region of Greece and their potential value to risk assessment and disaster management. Nat Haz 25:195-224

Dotterweich M, Schmitt A, Schmidtchen G, Bork H-R (2003) Quantifying historical gully erosion in northern Bavaria. Catena 50:135-150

Duffy E (1992) The stripping of the altars. Traditional religion in England c.1400-c.1580. Yale University Press, London

Dyer C (1989) Standards of living in the later Middle Ages. Social change in England c.1200-1520. Cambridge University Press, Cambridge

Dyer C (1992/1993) The great fire of Shipston-on-Stour. Warwickshire History 8:179-194

Dyer C (2010) The crisis of the early fourteenth century. Some material evidence from Britain. In: Boisseuil D, Chastang P, Feller L, Morsel J (eds) Écritures de l'espace social. Mélanges d'histoire medieval offerts à Monique Bourin. Sorbonne, Paris, pp 491-506

Espinar Moreno M, Quesada Gómez JJ (1991) Estudios sobre la ciudad de Baza en época musulmana y morisca. Los efectos del terremoto de 1531 en la estructura urbana. Miscelánea de Estudios Árabes y Hebraicos 30-31:87-109

Fäh D, Gisler M, Jaggi B, Kästli P, Lutz T, Masciadri V, Matt C, Mayer-Rosa D, Rippmann D, SchwarzZanetti G, Tauber J, Wenk T (2009) The 1356 Basel earthquake: an interdisciplinary revision. Geophys J Int 178:351-374

Fedi ME, Arnoldus-Huyzendveld A, Cartocci A, Manetti M, Taccetti F (2007) Radiocarbon dating in lateRoman and medieval contexts: an archaeological excavation in the Center of Florence, Italy. Radiocarbon 49(2):611-616

Fenoaltea S (1975) The rise and fall of a theoretical model: the manorial system. J Econ Hist 35:386-409

Férnandez Gracia R (2002) Monasterio de Fitero. Primer monasterio cisterciense de la Peninsula. Edilesa, León

Finucane RC (1995) Miracles and pilgrims. Popular beliefs in medieval England. Macmillan, Basingstoke

Fitzko F, Suhadolc P, Aoudia A, Panza GF (2005) Constraints on the location and mechanism of the 1511 Western-Slovenia earthquake from active tectonics and modelling of macroseismic data. Tectonophysics 404:77-90

Flynn MM (1985) Charitable ritual in late medieval and early modern Spain. Sixt Century J 16(3):335-348

Galadini F, Galli P (2001) Archaeoseismology in Italy: case studies and implications on long-term seismicity. J Earthq Eng 5:35-68

Galadini F, Hinzen K-G, Stiros S (2006) Archaeoseismology: methodological issues and procedure. J Seismol 10:395-414

Galli PAC, Naso JA (2009) Unmasking the 1349 earthquake source (southern Italy): paleoseismological and archaeoseismological indications from the Aquae Iuliae fault. J Struct Geol 31:128-149

Galloway JA, Potts JS (2007) Marine flooding in the Thames Estuary and tidal river c.1250-1450: impact and response. Area 39(3):370-379

Gerrard CM (2011) Contest and cooperation: strategies for medieval and later irrigation along the upper Huecha valley, Aragón, north-east Spain. Water Hist 3:3-28

Getz FM (1991) Black death and the silver lining: meaning, continuity, and revolutionary change in histories of medieval plague. J Hist Biol 24(2):265-289

Gilchrist R (2008) Magic for the dead? The archaeology of magic in later medieval burials. Med Arch 52:119-159

Gilchrist R (2012) Medieval life. Archaeology and the life course. Boydell, Woodbridge

Gilmour BJJ, Stocker DA (1986) St. Mark's Church and cemetery. The archaeology of Lincoln XIII-1, Lincoln

Gottschalk MKE (1975) Storm surges and river floods in the Netherlands I (the period 1400-1600). Van Gorcum, Assen

Gross A, Butcher A (1995) Adaption and investment in the age of the great storms: agricultural policy on the manors of the principal lords of the Romney Marshes and the marshland fringe, c.1250-1320. In: 
Eddison J (ed) Romney Marsh. The debatable ground. Oxford University Committee for Archaeology Mono 41, pp 107-117

Guidoboni E, Comastri A (1997) The large earthquake of 8 August 1303 in Crete: seismic scenario and tsunami in the Mediterranean area. J Seismol 1:55-72

Guidoboni E, Ebel JE (2009) Earthquakes and tsunamis in the past. A guide to techniques in historical seismology. CUP, Cambridge

Guidoboni E, Ferrari G (1995) Historical cities and earthquakes: Florence during the last nine centuries and evaluations of seismic hazard. Ann Geophys 38:617-647

Guidoboni E, Ferrari G (2000) The effects of earthquakes in historical cities; the peculiarity of the Italian case. Ann Geophys 43(4):667-686

Halstead P, Jones G (1989) Agrarian ecology in the Greek islands: time, stress, scale and risk. J Hell Stud 109:41-55

Hart R (1864) The shrines and pilgrimages of the county of Norfolk. Norfolk Norwich Archaeol Soc Trans 6:277-294

Harvey JH (1981) Medieval gardens. Batsford, London

Heidinga HA (1987) Medieval settlement and economy north of the lower Rhine. Archaeology and history of Kootwijk and the Veluwe (the Netherlands). Van Gorcum, Assen

Herget J, Meurs H (2010) Reconstructing peak discharges for historic flood levels in the city of Cologne, Germany. Glob Planet Chang. doi:10.1016/j.gloplacha.2009.11.011

Herteig AE (1959) The excavation of 'Bryggen', the old Hanseatic Wharf in Bergen. Med Archaeol 3:177-186

Jack RI (1979) The five ordinances of Ruthin 1364. Trans Denbighshire Hist Soc 28:5-17

Jones EL (1981) The European Miracle: environments, economies and geopolitics in the history of Europe and Asia. CUP, Cambridge

Jones G (ed) (2003) Saints of Europe: studies towards a survey of cults and culture. Shaun Tyas, Donington

Jones EL, Porter S, Turner M (1984) A gazetteer of British urban fire disasters, 1500-1900. Geo Books, Norwich

Jordan W (2009) Charms to ward off pig and sheep murrain. In: Rubin M (ed) Medieval Christianity in practice. Princeton University Press, Princeton, pp 67-74

Kalopissi-Verti S (1992) Dedicatory inscriptions and donor portraits in thirteenth-century churches of Greece. Oestereichische Akademie der Wissenschaften, Phil. Hist Klasse Denkschriften 226: Band

Keene D (2011) Crisis management in London's food supply, 1250-1550. In: Dodds B, Liddy CD (eds) Commercial activity, markets and entrepeneurs in the Middle Ages: essays in honour of Richard Britnell . The Boydell Press, Woodbridge, pp 45-62

Keevill G (1992) Life on the edge: archaeology and alluvium at Redlands Farm, Stanwick, Northamptonshire. In: Needham S, Macklin MG (eds) Alluvial archaeology in Britain, vol 27. Oxbow Monograph, Oxford, pp 177-184

Kershaw I (1973) The great famine and agrarian crisis in England 1315-1322. Past Present 59:3-50

Kingsford CL (ed) (1908) In: Stow J (ed) Survey of London (1598). Clarendon Press, Oxford

Kirchner H (2010) Por una arqueología agraria. Perspectivas de investigación sobre espacios de cultivo en las sociedades medievales hispánicas. BAR international series 2062. Archaeopress, Oxford

Kleinhans MG, Weerts HJT, Cohen KM (2010) Avulsion in action: reconstruction and modelling sedimentation pace and upstream flood water levels following a medieval tidal-river diversion catastrophe (Biesbosch, The Netherlands, 1421-1750 AD). Geomorphology 118:65-79

Korjenkov AM, Arrowsmith JR, Crosby C, Mamyrov E, Orlova LA, Povolotskaya IE, Tabaldiev K (2006) Seismogenic destruction of the Kamenka medieval fortress, northern Issyk-Kul region, Tien Shan (Kyrgyzstan). J Seismol 10:431-442

Lang A, Bork H-R (2006) Past soil erosion in Europe. In: Boardman J, Poesen J (eds) Soil erosion in Europe. Wiley, Chichester, pp 465-476

Le Goff J (1978) La Baja Edad Media, vol 11. Historia Universal Siglo XXI, Madrid

Lewin J (2010) Medieval environmental impacts and feedbacks: the lowland floodplains of England and Wales. Geoarchaeology 25(3):267-311

Luque L, Lario J, Zazo C, Goy JL, Dabrio CJ, Silva PG (2001) Tsunami deposits as paleoseismic indicators: examples from the Spanish coast. Acta Geol Hispanica 36(3-4):197-211

Macklin MG, Jones AF, Lewin J (2010) River response to rapid Holocene environmental change: evidence and explanation in British catchments. Quat Sci Rev 29:1555-1576

Malalana Ureña A (1997) Un conjunto de pulseras de vidrio hallado en la excavación del hospital de San Andrés. Boletín de Arqueología Medieval 11:293-312

Malanima P (2009) Pre-modern European economy. One thousand years (10th-19th centuries). LeidenBoston, Brill 
Mann ME, Zhang Z, Rutherford S, Bradley RS, Hughes MK, Shindell D, Ammann C, Faluvegi G, Ni F (2009) Global signatures and dynamical origins of the little ice age and medieval climate anomaly. Science 326(5957):1256-1260

Martin D, Martin B (2004) New Winchelsea, Sussex: a medieval port town. Field archaeology unit monograph no. 2. University College London, London

Martín-Vide J, Barriendos Vallvé M (1995) The use of rogation ceremony records in climatic reconstruction: a case study from Catalonia (Spain). Clim Chang 30:201-221

Mauelshagen F (2007) Flood disasters and political culture at the German North Sea coast: a long-term historical perspective. Hist Soc Res 32(3):133-144

McCloskey DN (1991) The prudent peasant: new findings on open fields. J Econ Hist 51(2):343-355

McRee BR (1993) Charity and gild solidarity in late medieval England. J Brit Stud 32(3):195-225

Meier D (2004) Man and environment in the marsh area of Schleswig-Holstein from Roman until late medieval times. Quat Int 112:55-69

Miller M (1996) Chartres cathedral. Pitkin, Andover

Mitchell JT (2003) Prayer in disaster: case study of Christian clergy. Nat Haz Rev 4(1):20-26

Molin D, Rossi A, Tertulliani A, Verrubbi V (2002) Studio della sismicità dell'altobacino dell'Aniene (Appennino Centrale-Italia) e catalogo sismico di area. Quaderni di Geofisica 24:1-37

Morris R (1989) Churches in the landscape. Dent, London

Murphy M, Potterton M (2010) The Dublin region in the Middle Ages. Settlement, land-use and economy. Four Courts Press, Dublin

Musson R (2012) The million death quake. Palgrave MacMillan, London

Nazzaro A (1998) Some considerations on the state of Vesuvius in the Middle Ages and the precursors of the 1631 eruption. Ann Geophys 41:555-565

Newfield TP (2009) A cattle panzootic in early fourteenth-century Europe. Agric Hist Rev 57(2):155-190

Oliver-Smith A (1986) Disaster context and causation: an overview of changing perspectives in disaster research. In: Oliver-Smith A (ed) Natural disasters and cultural contexts. Studies in third world societies, vol 36. College of William and Mary, Williamsburg, pp 1-34

Olivera Serrano C (1995) La actividad sísmica en el reino de Granada (1487-1531). Marcial Pons, Madrid

Oppenheimer C (2003) Ice core and palaeoclimatic evidence for the timing and nature of the great mid-13th century volcanic eruption. Int J Climatol 23:417-426

Papadopoulos GA, Fokaefs A (2005) Strong tsunamis in the Mediterranean Sea: a re-evaluation. ISET J Earthq Technol 42(4):159-170

Papadopoulos GA, Daskalaki E, Fokaefs A, Giraleas N (2007) Tsunami Hazard in the eastern Mediterranean: strong earthquakes and tsunamis in the east Hellenic arc and trench system. Nat Hazard Earth Syst Sci 7:57-64

Peláez JA, Castillo JC, Sánchez Gómez M, Martínez Solares JM, López Casado C (2005) Fuentes medievales y posibles evidencias arqueológicas del terremoto de Andújar de 1170. Boletín del Inst. de Estudios Giennenses 192:139-177

Pevsner N, Metcalf P (1985) The cathedrals of England: Midland, Eastern and Northern England. Viking, Harmondsworth

Piccardi L, Masse WB (2007) Myth and geology. Geological Society of London Special Publication, London, p 273

Piervitali E, Colacino M (2001) Evidence of drought in western Sicily during the period 1565-1915 from liturgical offices. Clim Chang 49:225-238

Pribyl K, Cornes RC, Pfister C (2011) Reconstructing medieval April-July mean temperatures in East Anglia, 1256-1431. Clim Chang. doi:10.1007/s10584-011-0327-y

Quarantelli EL (1998) What is a disaster? Perspectives on a question. Routledge, London

Rahtz PA (1970) Excavations on Glastonbury Tor, Somerset, 1964-6. Arch J 128:1-81

Rahtz PA, Hirst S (1976) Bordesley Abbey, Redditch, Hereford-Worcestershire. First report on excavations 1969-1972. British Archaeological Reports 3, Oxford

Ravensdale JR (1974) Liable to floods. Village landscape on the edge of the Fens AD 450-1850. CUP, Cambridge

Richardson G (2005) The prudent village: risk pooling institutions in medieval English agriculture. J Eco Hist 65:386-413

Rippon S (2000) The transformation of coastal wetlands: exploitation and management of marshland landscapes in North West Europe during the Roman and medieval periods. Brit Acad, London

Rippon S (2004) Making the most of a bad situation? Glastonbury Abbey, Meare, and the medieval exploitation of wetland resources in the Somerset Levels. Med Archaeol 48:91-130

Rohr C (2003) Man and natural disaster in the late middle ages: the earthquake in Carinthia and Northern Italy on 25 January 1348 and its perception. Environ Hist 9:127-149 
Rohr C (2007) Writing a catastrophe. Describing and constructing disaster perception in narrative sources from the Late Middle Ages. Hist Soc Res 32:88-102

Rosewell R (2008) Medieval wall paintings in English and Welsh churches. Boydell, Woodbridge

Ryan WG (ed and trans) (1993) Jacobus de Voragine, the golden legend, readings on saints I. Princeton University Press, Princeton

Salicrúi Lluch R (1995) The 1448 earthquake in Catalonia. Some effects and local reactions. Ann Geophys 38:503-513

Samuel M (1989) The fifteenth-century garner at Leadenhall, London. Antiq J LXIX:119-153

Scheffers A, Kelletat D, Vött A, May SM, Scheffers S (2008) Late Holocene tsunami traces on the western and southern coastlines of the Peloponnesus (Greece). Earth Planet Sci Lett 269:271-279

Schenk GJ (2007) '....prima ci fu la cagione de la mala provedenza de' Fiorentini...' Disaster and 'life world'-reactions in the commune of Florence to the flood of November 1333. Mediev Hist J 10:355-386

Schenk GJ (2010) Dis-astri. Modelli interpretativi delle calamità naturali dal Medioevo al Rinascimento. In: Maltheus M, Piccinni G, Pinto G, Varanini GM (eds) Le calamità ambientali nel tardo Medioevo Europeo: realtà, percezioni, reazioni. Firenze University Press, Firenze, pp 23-76

Schwarz-Zanetti G, Masciadri V, Fäh D, Kästli P (2008) The false Basel earthquake of May 12, 1021. J Seismol 12(1):125-129

Scribner RW (1984) Ritual and popular religion in Catholic Germany at the time of the Reformation. J Ecclesiast Hist 35(1):47-77

Silveira D, Gaspar JL, Ferreira T, Queiroz G (2003) Reassessment of the historical seismic activity with major impact on S. Miguel Island (Azores). Nat Haz Earth Syst Sci 3:615-623

Smith K, Petley DN (2009) Environmental hazards. Assessing risk and reducing disaster. Routledge, London

Smoller L (2000) Of earthquakes, hail, frogs and geography: plague and the investigation of the Apocalypse in the Later Middle Ages. In: Bynum CW, Feedman P (eds) Last things. Death and the Apocalypse in the Middle Ages. University of Pennsylvania Press, Pennsylvania, pp 156-187

Spufford P (2002) Power and profit. The merchant in medieval Europe. Thames and Hudson, London

Stiros SC (2000) Fault pattern of Nisyros Island volcano (Aegean Sea, Greece): structural, coastal and archaeological evidence. In: McGuire WG, Griffiths DR, Hancock PL, Stewart S (eds) The archaeology of geological catastrophes. Geological Society Special Publication no. 171, London, pp 385-397

Stothers RB (1999) Volcanic dry fogs, climate cooling, and plague pandemics in Europe and the Middle East. Clim Chang 42:713-723

Stothers RB (2000) Climatic and demographic consequences of the massive volcanic eruption of 1258. Clim Chang 45:361-374

Surtz RE (2001) Morisco women, written texts, and the Valencia inquisition. Sixt Century J 32(2):421-433

Taylor CC (1983) Village and farmstead. A history of rural settlement in England. George Philip, London

Tinti S, Maramai A (1996) Catalogue of tsunamis generated in Italy and in Côte d'Azur, France: a step towards a unified catalogue of tsunamis in Europe. Ann Geophys 39:1253-1299

Tittler R (1990) For the "re-edification of Townes": the rebuilding statutes of Henry VIII. Albion 22(4):591-605

Tol RSJ, Langen A (2000) A concise history of Dutch river floods. Clim Chang 46:357-369

Tragbar K (2006) "De Hedificiis Communibus Murandis ..." Notes on the beginning of building regulations in medieval Tuscany. In: Dunkeld M, Cambell J, Louw H, Tutton M (eds) Proceedings of the second international congress on construction history. Construction History Society, Cambridge, pp 3117-3131

Van Doesburg J (2009) Fighting against wind and sand. Settlement development in the coastal dunes and the cover sand region in the central Netherlands in the Middle Ages. In: Klápste J, Sommer P (eds) Medieval rural settlement in marginal landscapes. Ruralia VII. Brepols, Turnhout, pp 181-204

Vargas Jiménez JM (2002) Intervención arqueológica en la Hacienda de Miraflores de Sevilla. Anuario Arqueológico de Andalucía 3-2:299-310

Vaughan R (1986) The chronicles of Matthew Paris. Monastic life in the thirteenth-century life. Alan Sutton, Gloucester

Villanueva Muñoz EA (1986) La planificación urbana de Vera tras el terremoto de 1518: forma y significado. Roel: Cuadernos de civilización de la cuenca del Almanzora 7/8:127-143

Von Megenberg K (1861) Das Buch der Natur: die erste Naturgeschichte in deutscher Sprache (1309-1374). K. Aue, Stuttgart

Walsh K (2005) Risk and marginality at high altitudes: new interpretations from fieldwork on the Faravel Plateau, Hautes-Alpes. Antiquity 79(304):289-305 
Walsham A (2011) The reformation of the landscape. Religion, identity and memory in early modern Britain and Ireland. OUP, Oxford

Winterhalder B, Lu F, Tucker B (1999) Risk-sensitive adaptive tactics: models and evidence from subsistence studies in biology and anthropology. J Archaeol Res 7(4):301-348

Woolgar CM (2011) Gifts of food in late medieval England. J Mediev Hist 37(1):6-18

Wright SM (1976) Barton Blount: climatic or economic change? Med Archaeol 20:148-152

Zika C (1988) Host, processions and pilgrimages: controlling the sacred in fifteenth-century Germany. Past Present 118:25-64

Zuijderduijn J, De Moor T (2011) Spending, saving, or investing? Risk management in sixteenth-century Dutch households. Econ Hist Rev 66(1):38-56 